\title{
1800
}

\section{Reconnaissance Study of \\ Mississippian Siliciclastic Sandstones in Eastern Nevada}

GEOLOGY LIRRARY

Ueu - J

\section{U.S. GEOLOGICAL SURVEY BULLETIN 1988-I}

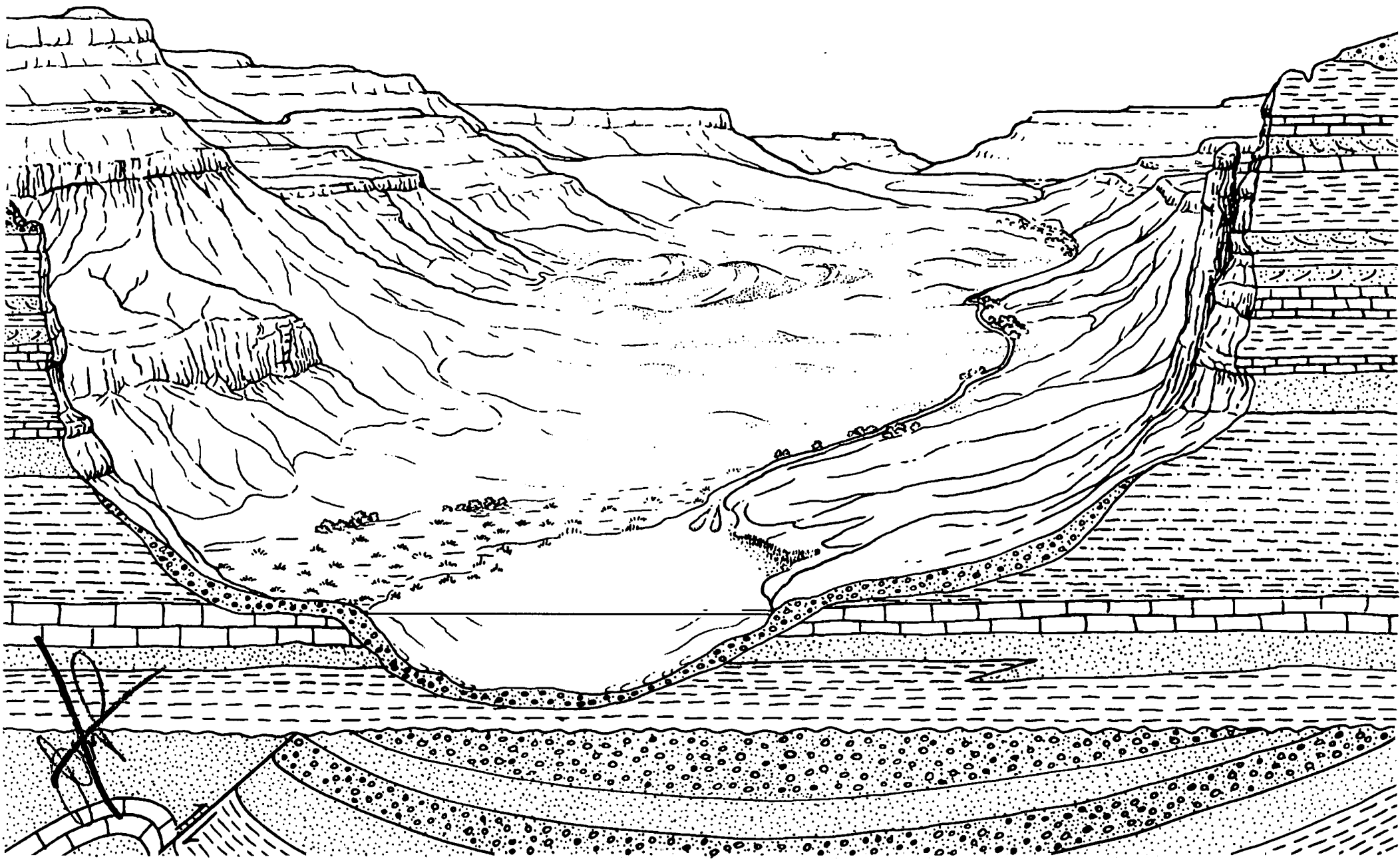




\section{AVAILABILITY OF BOOKS AND MAPS OF THE U.S. GEOLOGICAL SURVEY}

Instructions on ordering publications of the U.S. Geological Survey, along with prices of the last offerings, are given in the current-year issues of the monthly catalog "New Publications of the U.S. Geological Survey." Prices of available U.S. Geological Survey publications released prior to the current year are listed in the most recent annual "Price and Availability List." Publications that may be listed in various U.S. Geological Survey catalogs (see back inside cover) but not listed in the most recent annual "Price and Availability List" may no longer be available.

Reports released through the NTIS may be obtained by writing to the National Technical Information Service, U.S. Department of Commerce, Springfield, VA 22161; please include NTIS report number with inquiry.

Order U.S. Geological Survey publications by mall or over the counter from the offices listed below.

BY MAIL

\section{Books}

Professional Papers, Bulletins, Water-Supply Papers, Techniques of Water-Resources Investigations, Circulars, publications of general interest (such as leaflets, pamphlets, booklets), single copies of Earthquakes \& Volcanoes, Preliminary Determination of Epicenters, and some miscellaneous reports, including some of the foregoing series that have gone out of print at the Superintendent of Documents, are obtainable by mail from

\section{U.S. Geological Survey, Map Distribution \\ Box 25286, MS 306, Federal Center \\ Denver, CO 80225}

Subscriptions to periodicals (Earthquakes \& Volcanoes and Preliminary Determination of Epicenters) can be obtained ONLY from the

\section{Superintendent of Documents Government Printing Office Washington, DC 20402}

(Check or money order must be payable to Superintendent of Documents.)

\section{Map8}

For maps, address mail orders to

\section{U. S. Geological Survey, Map Distribution Box 25286, Bldg. 810, Federal Center Denver, CO 80225}

Residents of Alaska may order maps from

\author{
U.S. Geological Survey, Earth Science Information Center \\ 101 Twelfth Ave., Box 12 \\ Fairbanks, AK 99701
}

\section{OVER THE COUNTER}

\section{Books and Maps}

Books and maps of the U.S. Geological Survey are available over the counter at the following U.S. Geological Survey offices, all of which are authorized agents of the Superintendent of Documents.

- ANCHORAGE, Alaska-Rm. 101, 4230 University Dr.

- LAKEWOOD, Colorado-Federal Center, Bldg. 810

- MENLO PARK, California-Bldg. 3, Rm. 3128, 345 Middlefield Rd.

- RESTON, Virginia-USGS National Center, Rm. 1C402, 12201 Sunrise Valley Dr.

- SALT LAKE CITY, Utah-Federal Bldg., Rm. 8105, 125 South State St.

- SPOKANE, Washington-U.S. Post Office Bldg., Rm. 135, West 904 Riverside Ave.

- WASHINGTON, D.C.-Main Interior Bldg., Rm. 2650, 18 th and C Sts., NW.

\section{Maps Only}

Maps may be purchased over the counter at the following U.S. Geological Survey offices:

- FAIRBANKS, Alaska-New Federal Bldg, 101 Twelfth Ave.

- ROLLA, Missouri-1400 Independence Rd.

- STENNIS SPACE CENTER, Mississippi-Bldg. 3101 


\title{
Reconnaissance Study of Mississippian Siliciclastic Sandstones in Eastern Nevada
}

\author{
By Hugh McLean
}

EVOLUTION OF SEDIMENTARY BASINS-EASTERN GREAT BASIN

Harry E. Cook and Christopher J. Potter, Project Coordinators

U.S. GEOLOGICAL SURVEY BULLETIN 1988-I

A multidisciplinary approach to research studies of sedimentary

rocks and their constituents and the evolution of

sedimentary basins, both ancient and modern

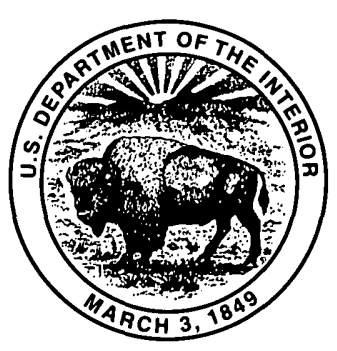

UNITED STATES GOVERNMENT PRINTING OFFICE, WASHINGTON : 1995 


\title{
U.S. DEPARTMENT OF THE INTERIOR \\ BRUCE BABBITT, Secretary
}

\author{
U.S. GEOLOGICAL SURVEY \\ Gordon P. Eaton, Director
}

For sale by U.S: Geological Survey, Information Services

Box 25286, Federal Center

Denver, CO 80225

\begin{abstract}
Any use of trade, product, or firm names in this publication is for descriptive purposes only and does not imply endorsement by the U.S. Government
\end{abstract}

\section{Library of Congress Cataloging-in-Publication Data}

McLean, Hugh, 1939-

Reconnaissance study of Mississippian siliciclastic sandstones in eastern Nevada / by Hugh McLean.

p. cm.-(Evolution of sedimentary basins-Eastern Great Basin ; ch. I)

(U.S. Geological Survey bulletin ; 1988-I)

Includes bibliographical references.

Supt. of Docs. no.: I 19.3:1988I

1. Sandstone-Nevada. 2. Geology, Stratigraphic-Mississippian. I. Title.

II. Series. III. Series: U.S. Geological Survey bulletin; 1988-I.

QE75.B9 no. 1988-I

[QE471.15.S25]

$557.3 \mathrm{~s}-\mathrm{dc} 20$

[552'.5] 


\section{CONTENTS}

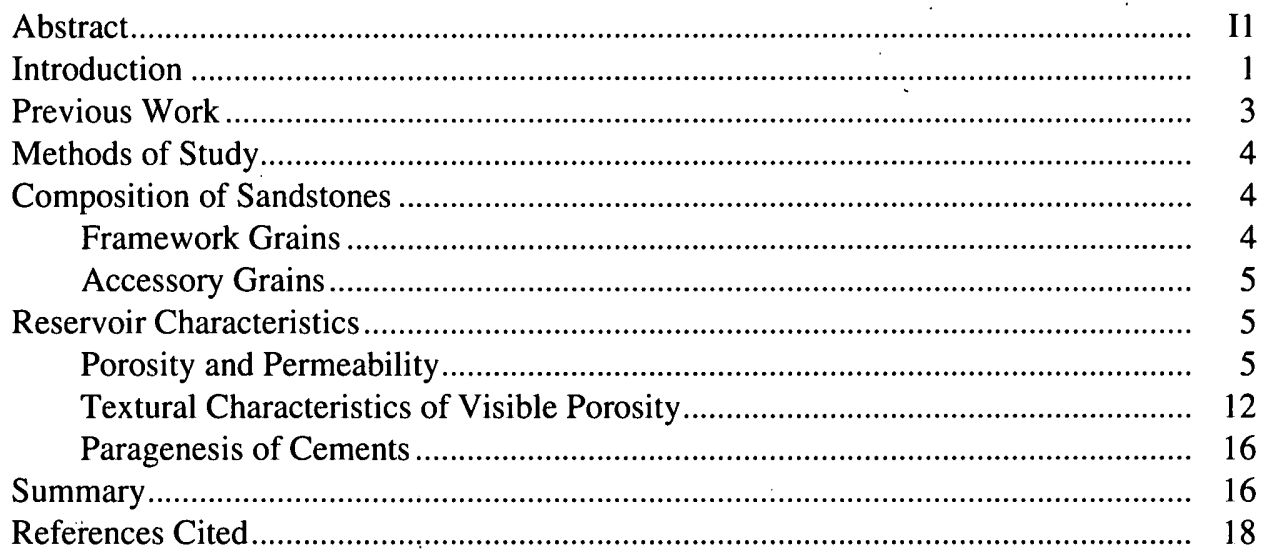

\section{FIGURES}

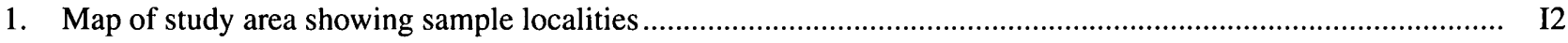

2. Time-rock correlation chart for Mississippian strata in eastern Nevada ......................................................... 3

3. Ternary diagrams showing detrital modes of Mississippian sandstones of east-central Nevada ......................... 11

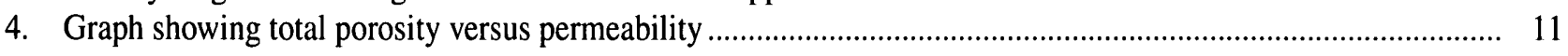

5. Graph showing total porosity versus visible porosity .............................................................................. 11

6-14. Photographs showing:

6. Shrinkage of pelitic rock fragment, Diamond Peak Formation ................................................................ 12

7. Porosity associated with dissolution of rock fragment, Diamond Peak Formation ....................................... 13

8. Porosity associated with dissolution of rock fragment, quartzose sandstone of the Scotty Wash Quartzite. 13

9. Secondary porosity, Diamond Peak Formation........................................................................................... 14

10. Secondary porosity and cementation, Diamond Peak Formation ........................................................ 14

11 Secondary pore formed by dissolution of calcareous cement, Diamond Peak Formation .......................... 15

12. Secondary porosity, Diamond Peak Formation............................................................................. 15

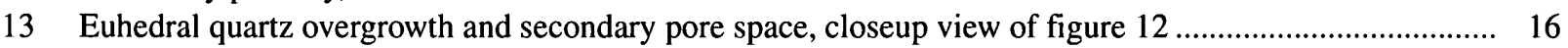

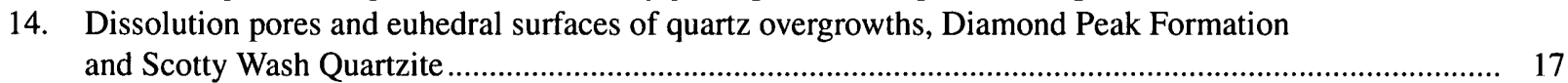

\section{TABLES}

1. Detrital modes for major framework constituents of Mississippian siliciclastic sandstones, eastern Nevada........ I6

2. Raw point-count data for all detrital constituents and porosity and permeability data for Mississippian siliciclastic sandstones, eastern Nevada 
.

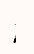




\title{
RECONNAISSANCE STUDY OF MISSISSIPPIAN SILICICLASTIC SANDSTONES IN EASTERN NEVADA
}

\author{
By Hugh McLean
}

\begin{abstract}
Siliciclastic sandstones of Mississippian age in some areas of east-central Nevada may be reservoir rocks for petroleum. Their reservoir potential derives from their stratigraphic proximity to organic-rich shales that have probably generated oil in the past and from their local porosity and permeability. The quality of these reservoir sandstones has been adversely affected, however, by two processes-early calcareous intergranular cementation and (or) pervasive quartz cementation associated with hydrothermally elevated temperatures. In areas having mature to supermature (hydrothermal?) thermal indices sandstones are invariably tightly cemented, whereas in areas having immature to mature thermal indices sandstone porosity and permeability locally are higher due to development of secondary porosity. Sandstones that contain pervasive intergranular calcite and (or) dolomite cement have low porosity and low permeability and minimal secondary porosity.

The siliciclastic sandstones contain a significant proportion of sedimentary lithic framework grains and conglomerate clasts that were transported generally eastward and southeastward from the uplifted Roberts Mountains allochthon during the Late Devonian and Early Mississippian Antler orogeny. Stratigraphic successions of Mississippian siliciclastic sandstones and conglomerates in eastern Nevada have been mapped variously as the Diamond Peak Formation (part), the Tonka Formation, the sandstone of Melandco, and the Scotty Wash Quartzite. Environments of siliciclastic deposition include submarine fans, deltaic and shallow-marine settings, and alluvial fans. The rocks are more quartzose with decreasing age and with distance from the allochthon; quartz sandstones of the Scotty Wash Quartzite locally may have been derived from a cratonic source(s).
\end{abstract}

\section{INTRODUCTION}

Siliciclastic rocks of Mississippian age that were derived from uplift and emplacement of the Roberts Mountains allochthon during the Antler orogeny extend from Idaho to southeastern California and are thickest and best exposed in central and eastern Nevada (fig. 1). Devonian rocks in eastern Nevada mainly consist of shelf-carbonate strata that accumulated in a tectonically stable environment along the western edge of the North American craton. In latest Devonian and Early Mississippian time, uplift and emplacement of the Roberts Mountain allochthon generated an influx of siliciclastic sediments that filled a narrow, elongate flysch trough that formed along the western edge of a foreland basin (Poole, 1974; Poole and Sandberg, 1991). Early workers in the area recognized that the siliciclastic detritus was derived from erosion of chert, siliceous mudrock, and sandstone of quartzose and arkosic composition that comprise what is now known as the Roberts Mountain allochthon (Nolan, 1928; Nolan and others, 1956).

Probably the most complete and best known Mississippian siliciclastic sequence in eastern Nevada is the Diamond Peak Formation (part). Approximately 2,000 m of Mississippian siliciclastic strata are well exposed in the Diamond Mountains in the eastern part of Eureka County, Nevada (figs. 1, 2). Both the Diamond Peak Formation and the underlying Chainman Shale in the Eureka district represent marine sediments that filled a flysch trough. The geologic characteristics of the Diamond Peak Formation in the Diamond Range have been described by Nolan and others (1956) and Brew $(1963,1971)$.

Trexler and Nitchman (1990) included the Chainman Shale and the lowermost part of the Diamond Peak Formation in a sequence that they named the Diamond Mountain sequence. They included the upper part of the Diamond Peak Formation in the Newark Valley sequence, a transgressive braid-delta sequence that unconformably overlies the flysch-trough fill of the Chainman Shale. Trexler and Cashman (1991) subsequently recognized that the unconformity-bounded stratigraphic sequences in the Diamond Mountains and northern Pancake Range resulted from multiple tectonic pulses or phases during the Antler orogeny. 


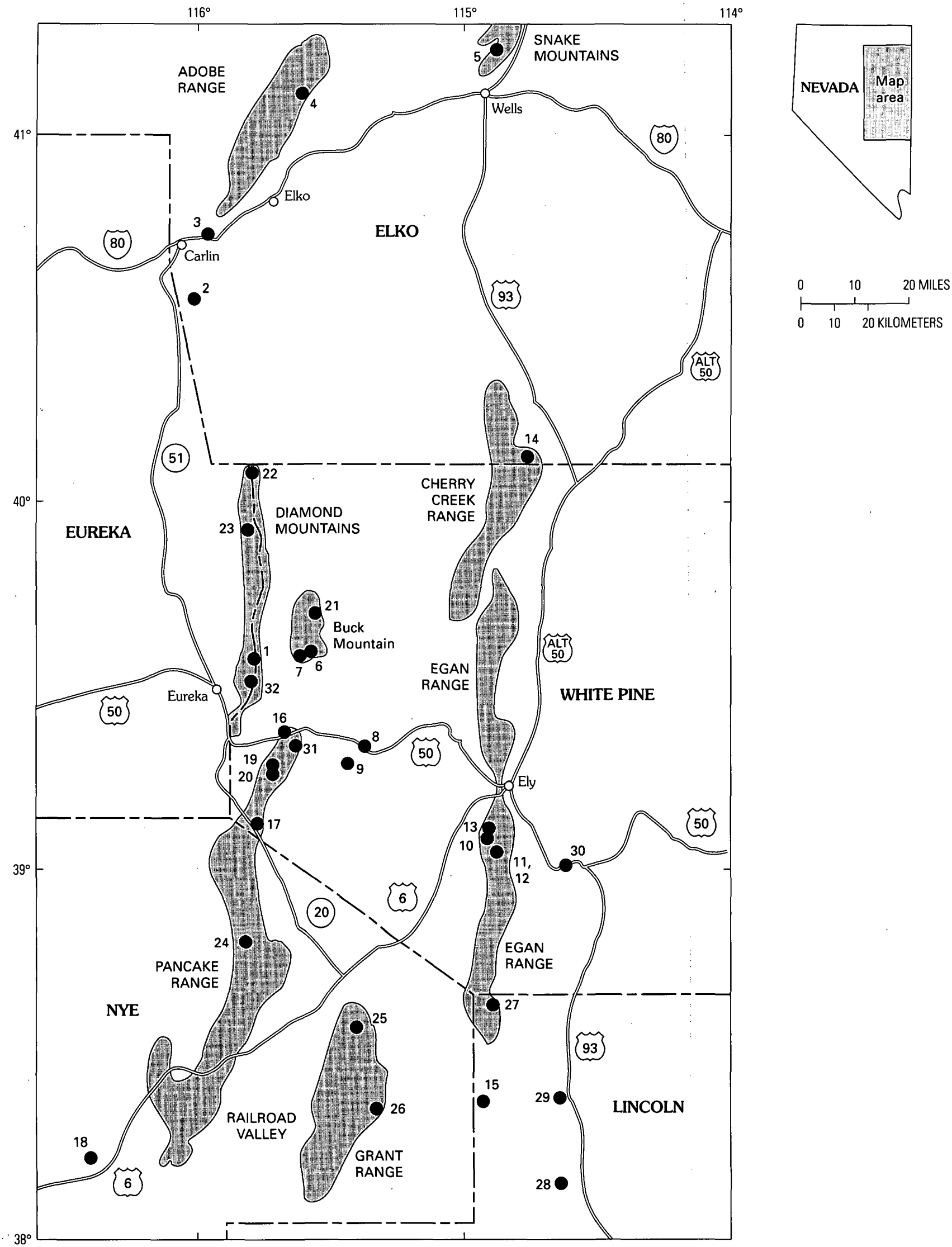

Figure 1. Map of study area showing sample localities. Numbered solid circles refer to locality number in column 1 of table 2 . 


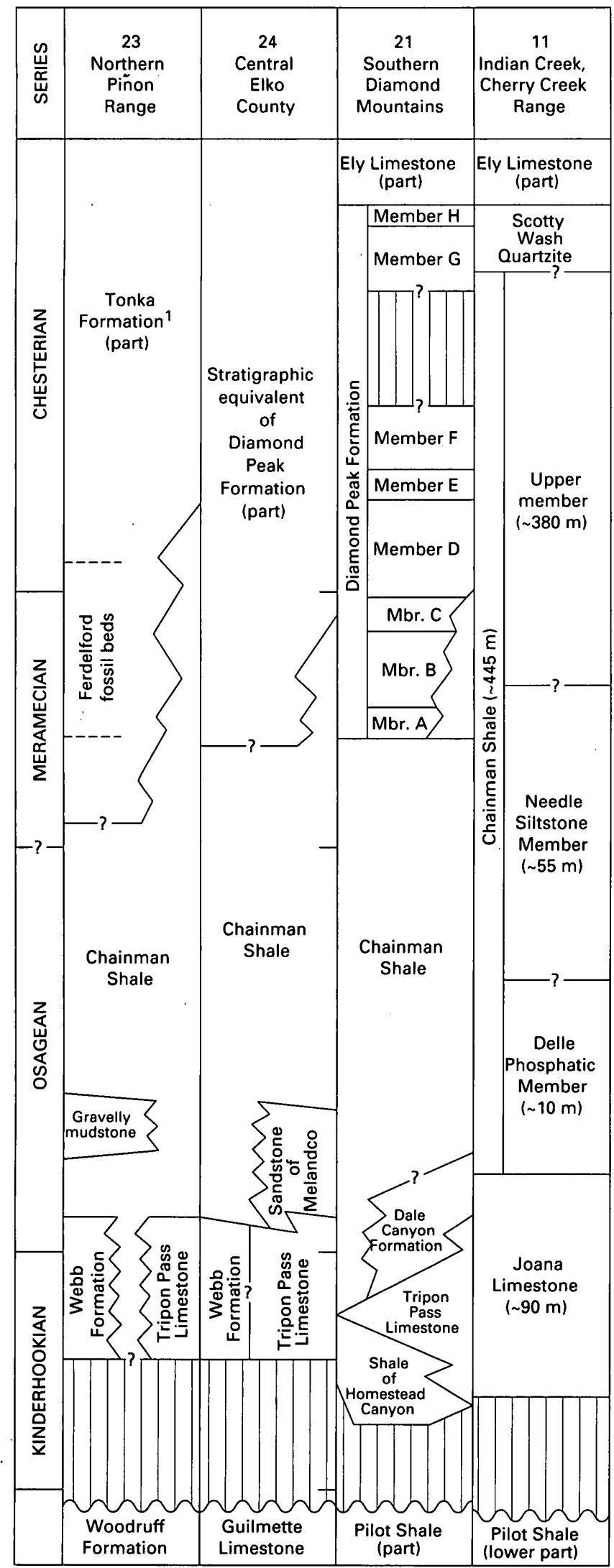

${ }^{1}$ Of Dott (1955)

Figure 2. Time-rock correlation chart for Mississippian strata in eastern Nevada. Modified from Poole and Sandberg (1991, p. 116 and 119, cols. 11, 21, 23, and 24 ).
Other Mississippian siliciclastic strata in eastern Nevada include the Tonka Formation, the Scotty Wash Quartzite and the sandstone of Melandco (fig. 2). The Tonka Formation, named by Dott (1955), consists of sandstone and conglomerate that crop out in the northern Piñon Range near Carlin, Nevada. Siliciclastic strata in the Adobe Range northwest of Elko and in the Snake Mountains north of Wells (fig. 1) were named the sandstone of Melandco by Poole and Sandberg (1991, p. 119). Sandstone that crops out east and southeast of the Pancake Range was named the Scotty Wash Quartzite by Westgate and Knopf (1932). Scotty Wash sandstones are more quartzose, thinner bedded, and finer grained than Diamond Peak sandstones; local well-developed trough crossbedding in the Scotty Wash suggests tidal or deltaic deposition. Columnar sections (Poole and Sandberg, 1991) suggest that the Scotty Wash Quartzite correlates with the upper part of the Diamond Peak and that the sandstone of Melandco correlates with the lower part of the Diamond Peak Formation (fig. 2). Stratigraphy and tectonism associated with the Antler orogeny are discussed in more detail by Trexler and Cashman $(1990,1991)$, Trexler and Nitchman (1990), Goebel (1991), Poole and Sandberg (1991), and Trexler and others (1991). Roberts and others (1967) provided a summary of early stratigraphic nomenclature in Eureka County and a geologic map of the western Diamond Mountains.

Published subsurface oil and gas exploration data from eastern Nevada suggest that, at least locally, Devonian limestone and organic-rich shale of the Mississippian Chainman Shale are potential hydrocarbon source rocks and that associated siliciclastic sandstones are potential reservoir rocks (Poole and others,1983; Poole and Claypool, 1984). In this report, I describe a reconnaissance study of reservoir characteristics (porosity and permeability) of Mississippian siliciclastic sandstones in areas exposed to different thermal regimes as determined by analyses of petroleum source-rock potential (Poole and Claypool, 1984).

Acknowledgments.-Petrographic study of the siliciclastic rocks of eastern Nevada was initially suggested by Harry E. Cook. Forrest G. (Barney) Poole subsequently introduced me to the siliciclastic rocks of eastern Nevada and provided technical and scientific advice throughout the duration of the project. Tom Bergstresser of Chevron USA, Houston, Texas, coordinated the laboratory analyses of porosity and permeability that contributed greatly to the study. Some of the thin sections used in this study were made by Barbara Lockett. David Brew kindly loaned a suite of thin sections from his dissertation area in the southern Diamond Mountains. Laura Zink provided assistance with preliminary computer graphics. Early drafts of the manuscript profited from reviews by Janet Pitman, Tom MacKinnon, and F.G. Poole.

\section{PREVIOUS WORK}

Petrologic studies by previous workers of the Diamond Peak Formation in the Diamond Mountains suggest that 
most of the detritus in the siliciclastic sequence was derived from rocks that now comprise the Roberts Mountains allochthon or Antler highland (Nolan, 1928; Brew, 1963, 1971; Harbaugh, 1980; Harbaugh and Dickinson, 1981). Sedimentary rock fragments of quartzose sandstone, siltstone, siliceous mudstone, pure and impure chert, and potassium feldspar-bearing arkosic sandstone are present within the Antler foreland (Dickinson and others, 1983).

Studies of provenance and composition of the Chainman Shale and Diamond Peak Formation in the central Diamond Range were reported by Brew (1963, 1971). Detrital modes, facies interpretations, and tectonic implications of the Diamond Peak Formation from an area immediately north of Brew's map area were reported by Harbaugh (1980) and recast by Harbaugh and Dickinson (1981) and Dickinson and others (1983). Trexler and Cashman (1991) reported paleocurrent data and selected detrital modes for the Newark Valley sequence in the Diamond, Pancake, and White Pine mountain ranges. Facies within the Newark Valley sequence in the Diamond Mountains were interpreted by Perry and Trexler (1993) as representing alluvial, deltaic, and shallow-marine environments, and detrital constituents within the Newark Valley sequence were interpreted as reflecting recycling of underlying strata. Together, the variation in facies and composition were interpreted by Perry and Trexler as indications of a tectonically active depositional setting.

\section{METHODS OF STUDY}

For the purposes of this study, 60 siliciclastic sandstone samples were collected from 31 sites in Elko, Eureka, White Pine, Nye, and Lincoln Counties of east-central Nevada (fig. 1). Thin sections were examined petrographically to determine composition of framework grains, type and volume of intergranular cements, and amount of visible pore space. Standard thin sections were stained with sodium cobaltinitrate for potassium feldspar and point counted using petrographic techniques outlined by Dickinson (1970). Most of the thin sections were impregnated with blue-dyed epoxy, which facilitated measurement of visible porosity. The Gazzi-Dickinson method described by Ingersoll and others (1984) was employed in counting polycrystalline rock fragments. Detrital modes shown in figure 3 and listed in table 1 are based on counts of $300-400$ framework grains per thin section; raw point counts and porosity and permeability data are given in table 2 . Counts of visible pore space (filled by blue-dyed epoxy) and intergranular cement increased the total number of counted points in some sections to as many as 655 (table 2).

Calcite and dolomite cements were identified in hand specimen by applying a drop of dilute $(2 \mathrm{~N}) \mathrm{HCl}$ to fresh surfaces. Samples that effervesced freely were considered to be cemented by calcite, whereas samples that effervesced only on a scratched surface were considered to be cemented with dolomite.

A suite of 27 sandstone samples was analyzed by the Western Exploration Technical Center of Chevron USA, Houston, Texas, for percentage of total porosity and permeability. Porosities were measured by the mercury intrusion technique, and permeabilities were measured by unstressed (air) and stressed (brine) techniques. Results of these analyses are given in table 2 .

\section{COMPOSITION OF SANDSTONES}

\section{FRAMEWORK GRAINS}

Detrital modes for samples of the Diamond Peak Formation and Scotty Wash Quartzite and for samples from locations north of the Diamond Mountains are shown in four ternary diagrams in figure 3 . The rocks in the "northern area" of figure 3 include the Tonka Formation of Dott (1955), the sandstone of Melandco in the Adobe Range and Snake Mountains, and the Diamond Peak Formation at Ferdelford Canyon in the northern Piñon Range (locality 2, fig. 1).

Quartz.-The QtFL and QmFLt diagrams of figure 3 illustrate the quartzose, subquartzose, and sublithic compositions of Mississippian siliciclastic sandstones of east-central Nevada. Most of the well-rounded monocrystalline quartz grains $(\mathrm{Qm})$ were probably recycled from eroded quartzose sandstone protoliths in the source area. Polycrystalline quartz (Qp, table 2) excludes chert and consists mainly of very fine grained quartzite. Well-rounded grains were probably recycled from sandstone in the source area.

Chert.-Grains of recrystallized chert (Ch) are common framework constituents in most of the Mississippian sandstones except for the Scotty Wash Quartzite. Well-rounded grains of chert were probably recycled from sandstone protoliths, whereas angular and subangular grains were probably derived from chert-bearing sequences in the source area such as the Ordovician Vinini Formation. The great variation in degree of both clarity and recrystallization of chert grains suggests the possibility of multiple sources.

Potassium feldspar.-Potassium feldspar is present in modest amounts (4-12 percent) in samples from the Adobe Range and Snake Mountains in the northern part of the area (Tonka Formation and sandstone of Melandco) and from the Diamond Peak Formation in the northern Pancake Range. One sample from the Diamond Peak Formation contained as. much as 19 percent potassium feldspar (table 2, locality 19). Potassium feldspar is also present as detrital grains in sandstone and siltstone rock fragments. Individual potassium feldspar framework grains were probably recycled from an arkosic sandstone protolith. Dickinson and others (1983) suggested that potassium feldspar in the Diamond Peak Formation was recycled from arkose in the Cambrian Harmony Formation. Local variations in potassium feldspar content 
may support the concept of Perry and Trexler (1993) that sediments comprising the Diamond Peak Formation in the Newark Valley sequence were reworked by local tectonic pulses. Alternatively, sediment availability and input from source rocks in the allochthon such as the Harmony Formation may have varied locally. Such variation through time could have affected potassium feldspar concentrations in resultant sediment accumulations.

Potassium feldspar in tightly compacted rocks that have little visible porosity shows no evidence of alteration. In rocks that have significant secondary porosity, grains of potassium feldspar are corroded and pitted.

Plagioclase.-Except for three samples from the Diamond Peak Formation (localities 1, 20, and 23, table 2), raw counts of plagioclase feldspar do not exceed six grains per thin section. Most plagioclase is subangular to subrounded, finely twinned albite. Plagioclase provenance remains problematic; possible sources include volcanic, recycled sedimentary, and plutonic rocks. Patchy mottling observed on some twinned grains might be a relict texture.

Sedimentary rock fragments.-Chert and siliciclastic sedimentary rock fragments dominate the population of lithic framework grains in samples from the Diamond Peak Formation, Tonka Formation, and sandstone of Melandco. The suite of lithologies includes potassium feldspar-bearing quartzofeldspathic sandstone and siltstone, argillaceous mudstone of varying brownish color and degree of opacity, and tuffaceous(?) mudstone that ranges from light-colored impure chert to colorless, nearly isotropic cryptocrystalline forms.

Metamorphic rock fragments.-Schistose rock fragments are present only in trace amounts in the Diamond Peak Formation and its northern correlatives and are absent in the Scotty Wash Quartzite. Pale-green chloritic grains were included as metamorphic rock fragments and make up the relatively large part of metamorphic grains counted in Diamond Peak sandstones at locality 19 (table 2).

Volcanic rock fragments.-Grains containing clearly discernible volcanic textures are very rare; however; those that were observed consisted of microlitic laths of albite set in a groundmass of light-brown, translucent glass.

Limeclasts.-Caicareous framework grains were noted in only a few geographically widely separated samples. This local occurrence suggests that intertongues of limestone may have provided an intraformational source for the limeclasts. Limestone interbeds in the Diamond Peak Formation were observed in the vicinity of locality 6 (table 2). Alternatively, limeclasts at locality 3 (Carlin Canyon) may have been derived from recycling of Paleozoic limestones that unconformably underlie the Tonka Formation (Dott, 1955).

Rock fragments of uncertain origin.-Cryptocrystalline grains that have no discernible texture or fabric were counted as rock fragments of uncertain origin. Although the general abundance of sedimentary rock fragments suggests that most of the grains in the uncertain-origin category are also probably sedimentary, a volcanic origin for some is possible.

\section{ACCESSORY GRAINS}

Mica.-Mica was observed in only a few samples from the Diamond Peak Formation and was notably absent in sandstones of the Scotty Wash Quartzite (table 2). In the few rocks that contained mica, the predominant variety was muscovite, although sparse grains of light-brown biotite were also noted.

Opaque grains.-Grains of opaque material are present sporadically in both the Diamond Peak Formation and Scotty Wash Quartzite. In sandstones adjacent to mineralized zones where elevated temperatures are presumably related to circulation of hydrothermal fluids (such as the Ward mining district, localities 10-12, table 2), the opaque grains are mainly pyrite. At Trough Spring Canyon (locality 15, table 2), however, dissolution of nonmetallic opaque grains that are pale orange in reflected light forms secondary pores.

\section{RESERVOIR CHARACTERISTICS}

\section{POROSITY AND PERMEABILITY}

Laboratory measurements of total porosity and permeability in air and brine are given together with visible porosity in table 2. Budget limitations prevented rocks from the Adobe and northern Piñon ranges and the Snake Mountains from being included in the suite of samples in which these parameters were measured. Total porosity within the sample suite ranged from 2.5 to 19.4 percent (fig. 4). Unstressed (air) permeability ranged from 0.32 to $420 \mathrm{mD}$ (fig. 4), whereas stressed (brine) permeability ranged from 0.10 to $370 \mathrm{mD}$. Visible porosity determined by point-counting ranged from 0 to 28 percent and correlates favorably with laboratory measurements (figure 5); in eight samples visible porosity is within 2 percent of total porosity.

Where petroleum source rocks are mature to supermature, such as the Ward mining district in the northern Egan Range and Dry Creek in the Cherry Creek Range (Poole and others, 1983) (localities 10-13, 14, fig. 1), quartz-cemented quartzose sandstone is uniformly well cemented; that is, porosity and permeability are minimal. In contrast, noncalcareous sandstones associated with immature to mature petroleum source rocks yielded highly variable values of porosity and permeability. For example, several samples from a small area in Trough Spring Canyon in the southern Egan Range (locality 15, fig. 1) ranged from 11.6 to 17.4 percent porosity and from 43 to $420 \mathrm{mD}$ permeability. Similarly, at the south end of Buck Mountain (locality 6, fig. 1), closely spaced samples ranged from 4.5 to 14.1 percent porosity and from 3 to $38 \mathrm{mD}$ permeability. Near Nevada Governors Spring in the northern Pancake Range (locality 17, fig. 1), porosity ranged from 8.4 to 13.1 percent and air permeability from 2.4 to $18 \mathrm{mD}$. The variations in porosity and permeability in noncalcareous and slightly calcareous sandstones are probably due to variables 


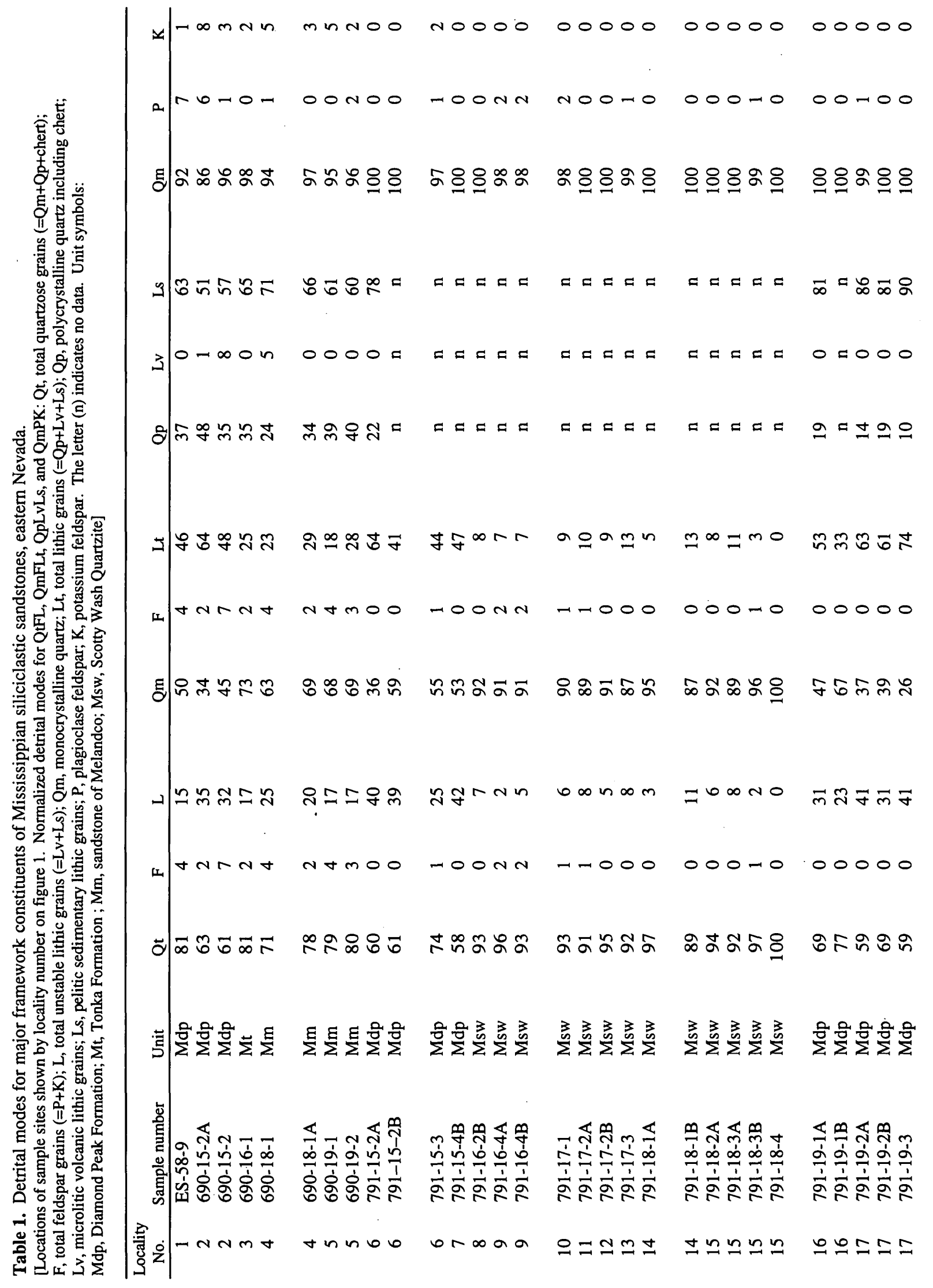




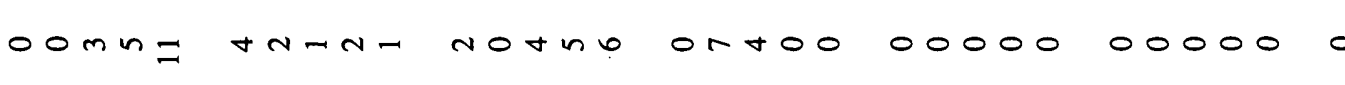

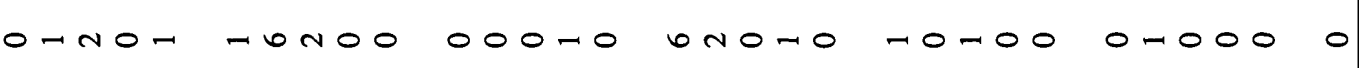

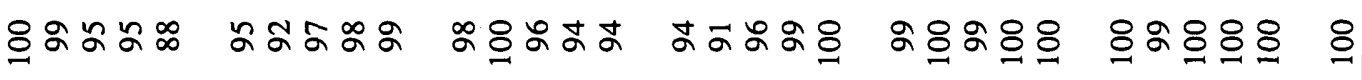

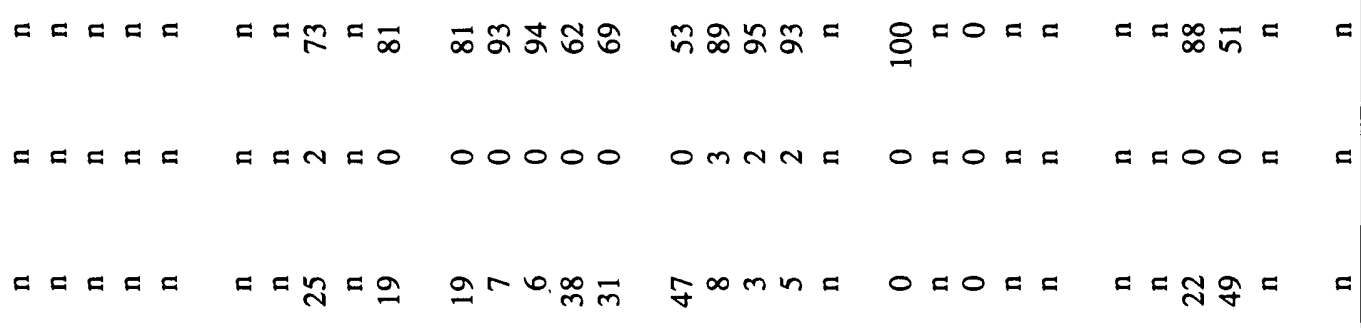

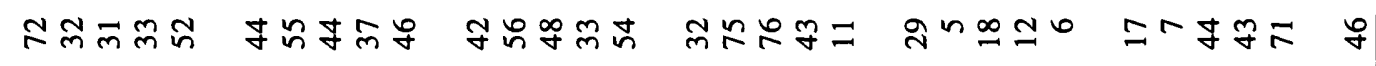

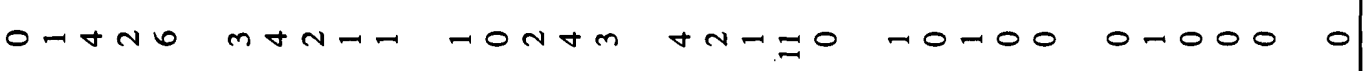

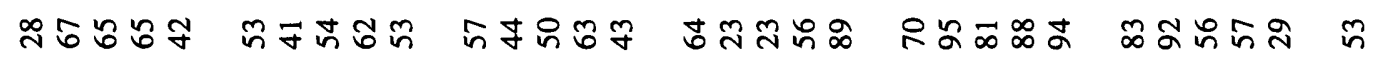

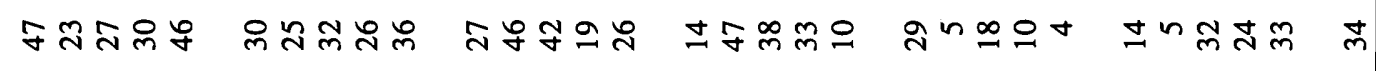

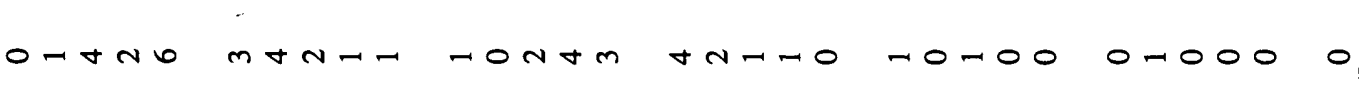

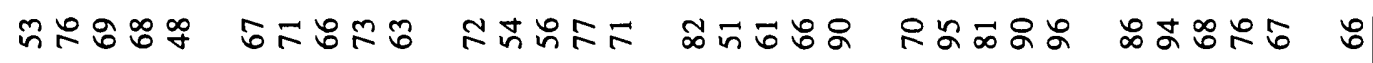

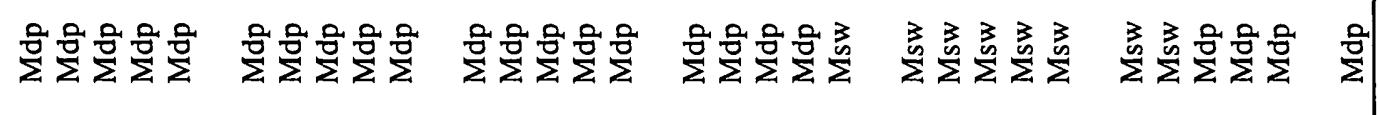

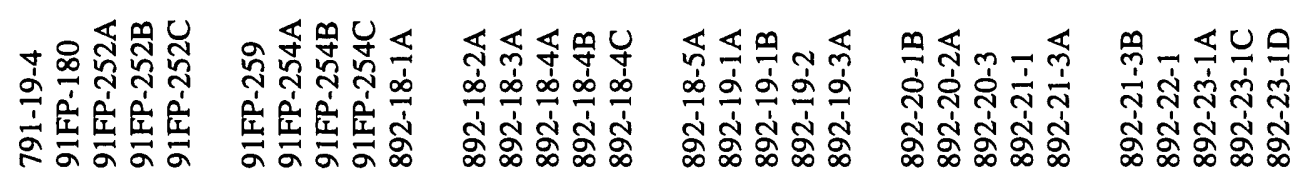

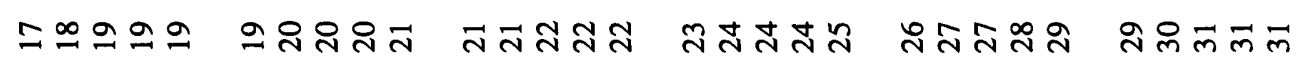




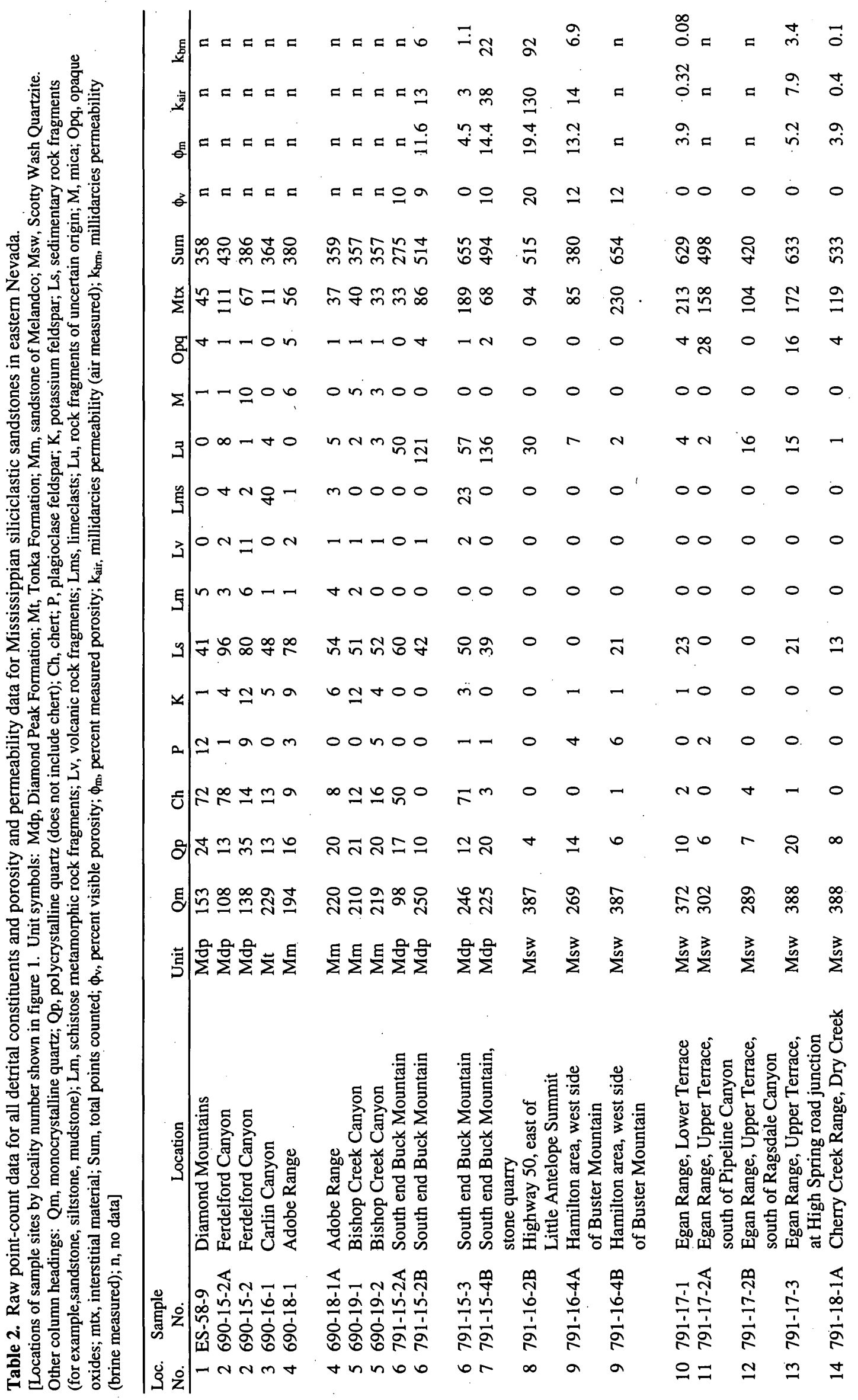




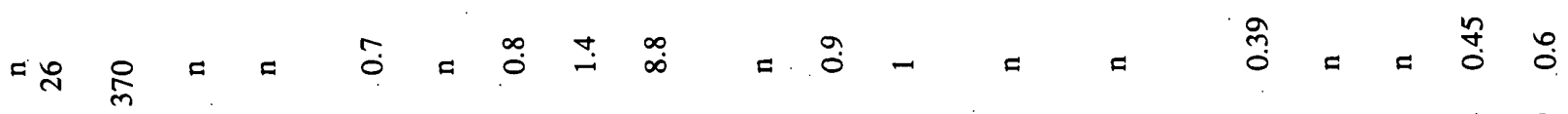

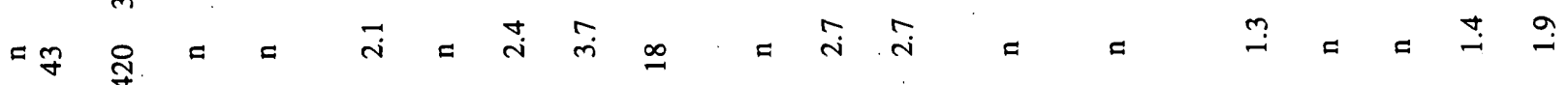

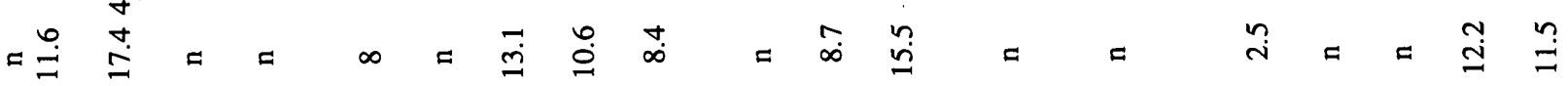

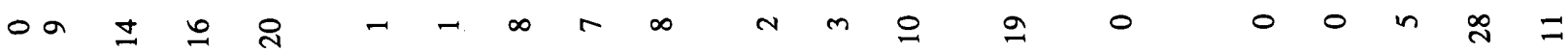

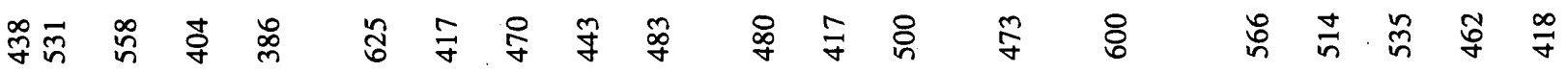

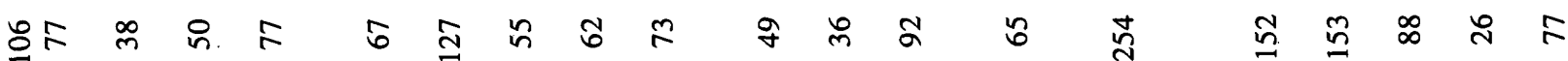

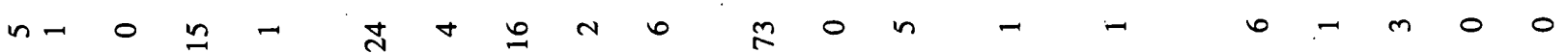

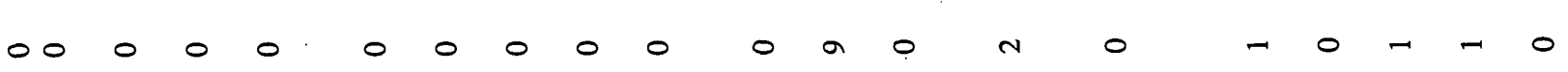

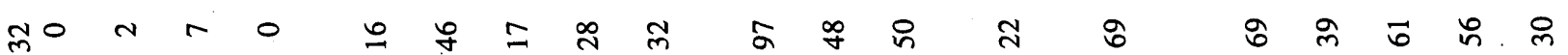

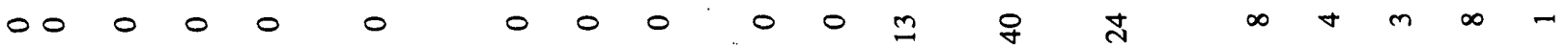
$0000000000-400$ 000000000000

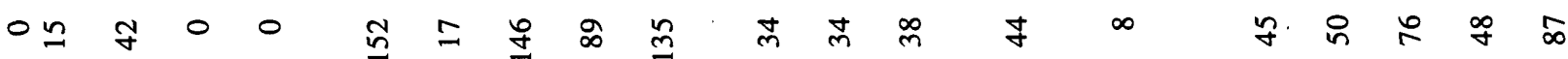

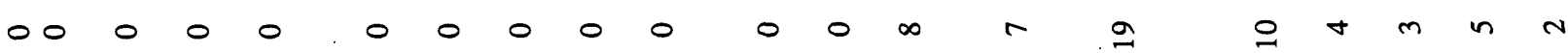

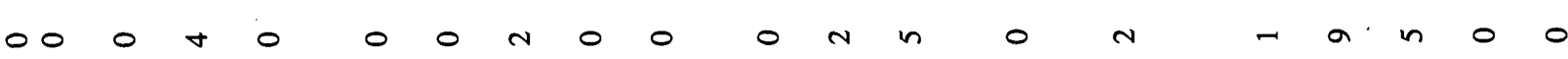

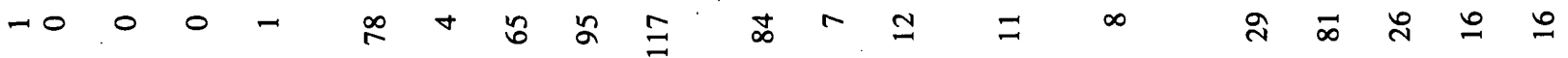

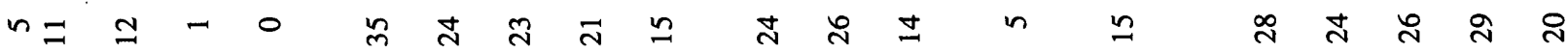

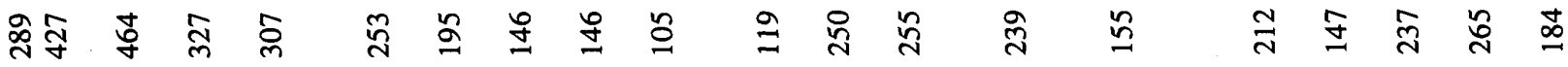

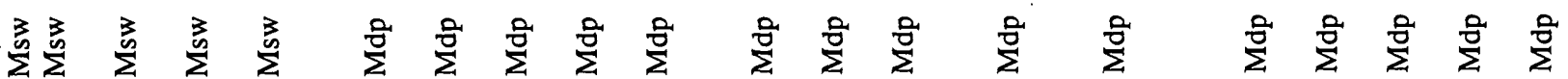

苋

\section{空}

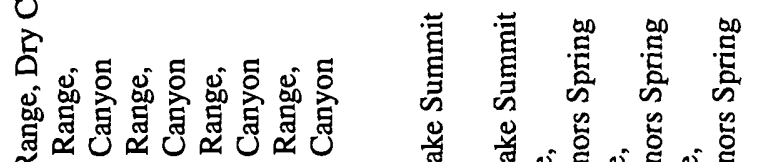

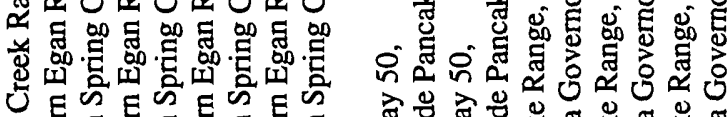

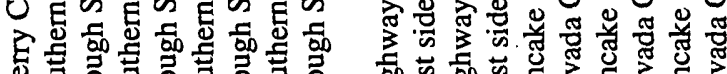
要

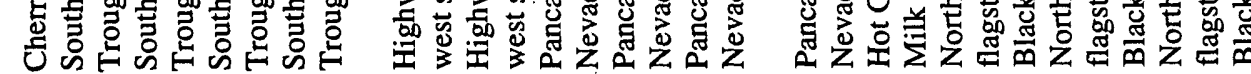

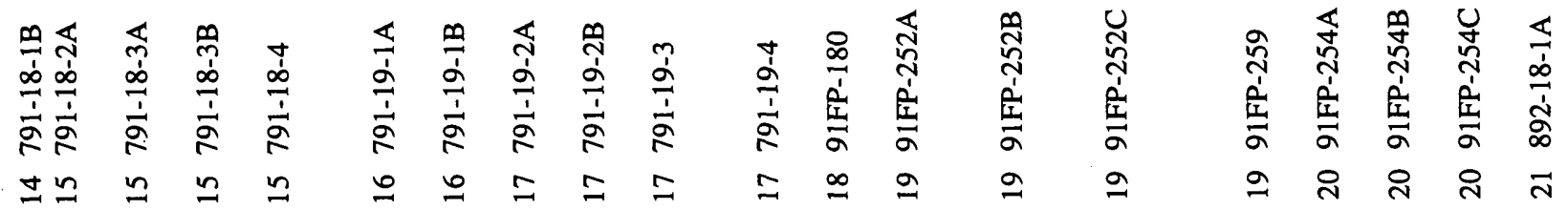




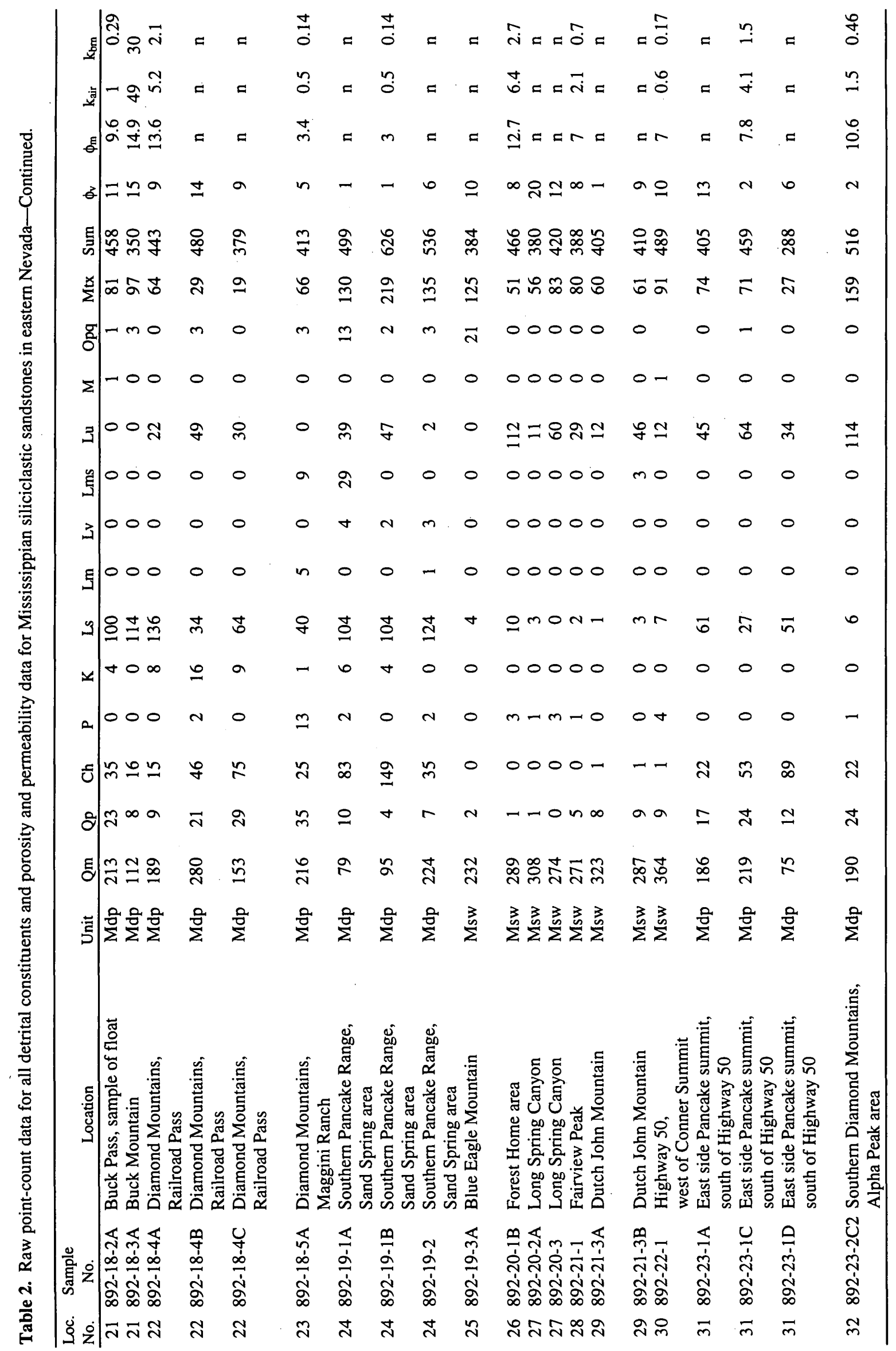



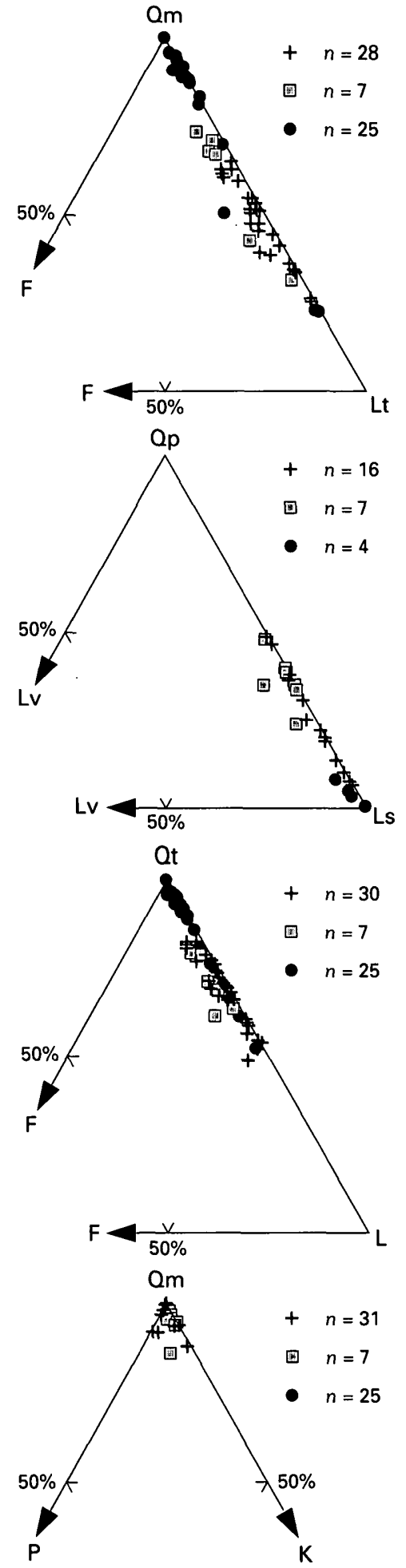

\section{EXPLANATION}

+ Diamond Peak Formation

ఐ Rocks of northern area

- Scotty Wash Quartzite
Figure 3 (facing column). Detrital modes of Mississippian sandstones of east-central Nevada. Qt, total quartzose grains $(=\mathrm{Qm}+\mathrm{Qp}+\mathrm{chert}) ; \mathrm{F}$, total feldspar grains $(=\mathrm{P}+\mathrm{K}) ; \mathrm{L}$, total unstable lithic grains $(=\mathrm{Lv}+\mathrm{Ls}) ; \mathrm{Qm}$, monocrystalline quartz; Lt, total lithic grains $(=\mathrm{Qp}+\mathrm{Lv}+\mathrm{Ls}) ; \mathrm{Qp}$, polycrystalline quartz including chert; Lv, microlitic volcanic lithic grains; Ls, pelitic sedimentary lithic grains; $P$, plagioclase feldspar; $K$, potassium feldspar.

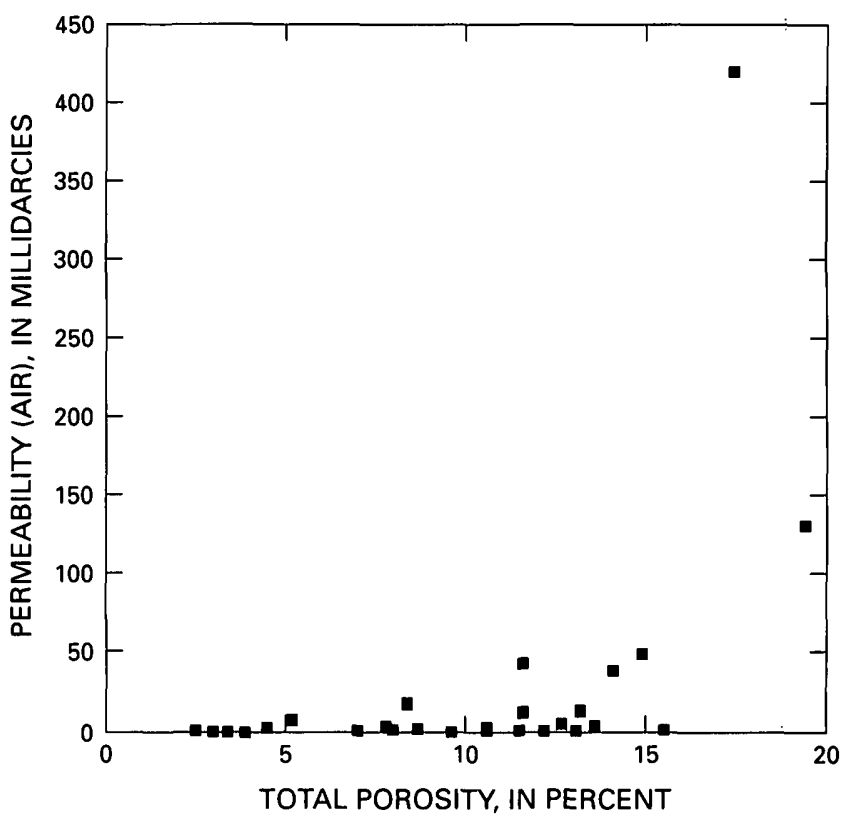

Figure 4. Total porosity versus permeability.

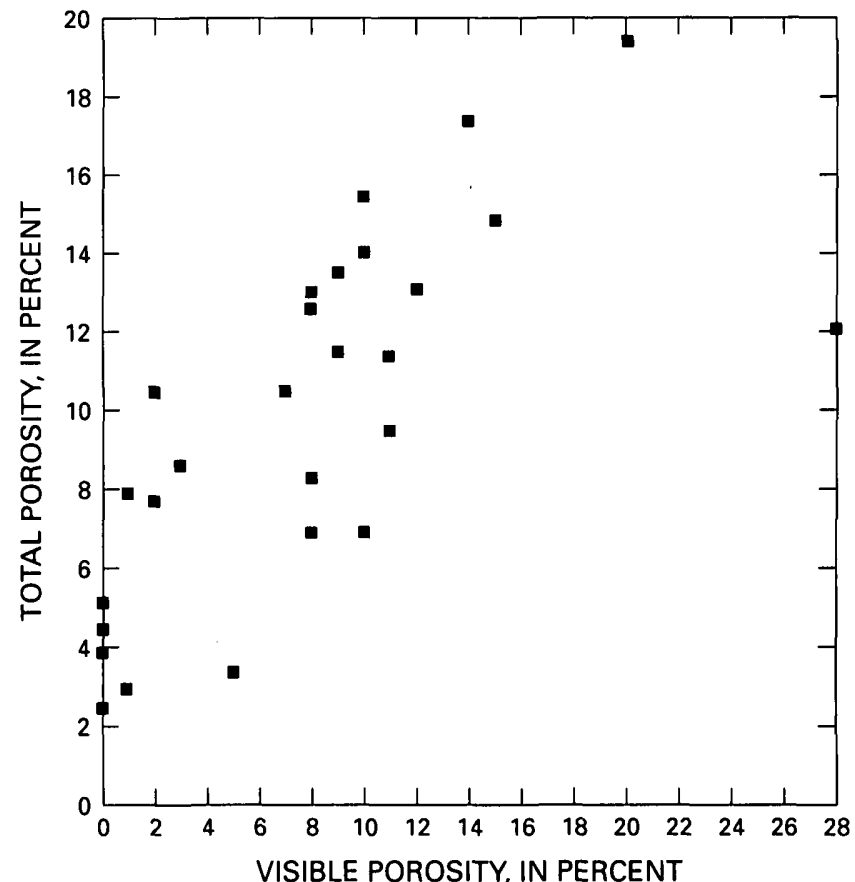

Figure 5. Total porosity versus visible porosity. 
associated with the development of secondary porosity such as ground-water temperature, $\mathrm{pH}$, and, flow gradients, as well as to the abundance of intergranular cements (calcite and (or) dolomite) and the degree of weathering.

\section{TEXTURAL CHARACTERISTICS OF VISIBLE POROSITY}

Visible pores in Mississippian siliciclastic rocks of eastern Nevada display many of the textural characteristics generally considered to be the result of secondary processes (Schmidt and McDonald, 1979; Melvin and Knight, 1984). Secondary porosity textures include grain shrinkage, dissolution of rock fragments, and dissolution of carbonate cement. Examples of these textures are clearly illustrated by blue epoxy in the photographs of figures 6-13 in which blue areas represent visible pore space. Figure 6 illustrates shrinkage of a sedimentary rock fragment that is surrounded by quartz grains. The concentric band within the rock fragment resembles a weathering rind that may have formed by reaction with pore fluids. Figures 7 and 8 illustrate porosity associated with dissolution of rock fragments. Opaque grains are particularly susceptible to dissolution (fig. 7). Figure 9 shows dissolution of rock fragments, as well as porosity due to grain fracture in a rock that has been mechanically compacted and cemented by quartz. Clusters of tightly compressed framework grains in rocks that have abundant visible pore space suggest that primary pore space in most cases was mostly reduced by mechanical compaction and further reduced by precipitation of quartz and (or) calcareous cement (figs. 7-9).

Both visible and total porosity are negligible in rocks that have pervasive calcareous cement. Tests on hand specimens with dilute $\mathrm{HCl}$ indicate that calcite and dolomite are common cements in the Mississippian rocks of eastern Nevada. Neither secondary porosity nor faceted quartz overgrowths were observed in the suite of calcareous rocks. Noncalcareous and sparsely calcareous sandstones commonly contain quartz grains that have faceted overgrowths, and visible pore spaces are commonly bordered by faceted quartz grains (figs. 10-13).

In addition to standard petrographic examination of visible pore space in thin sections impregnated with blue-dyed epoxy, the presence of dissolution pores and quartz overgrowths can also be rapidly and inexpensively determined by examining unimpregnated, diamond-sawed rock surfaces with a low-power binocular microscope. At relatively low magnification $(\times 24)$, reflected light flashes from faceted quartz overgrowths (fig. 14A) and dissolution

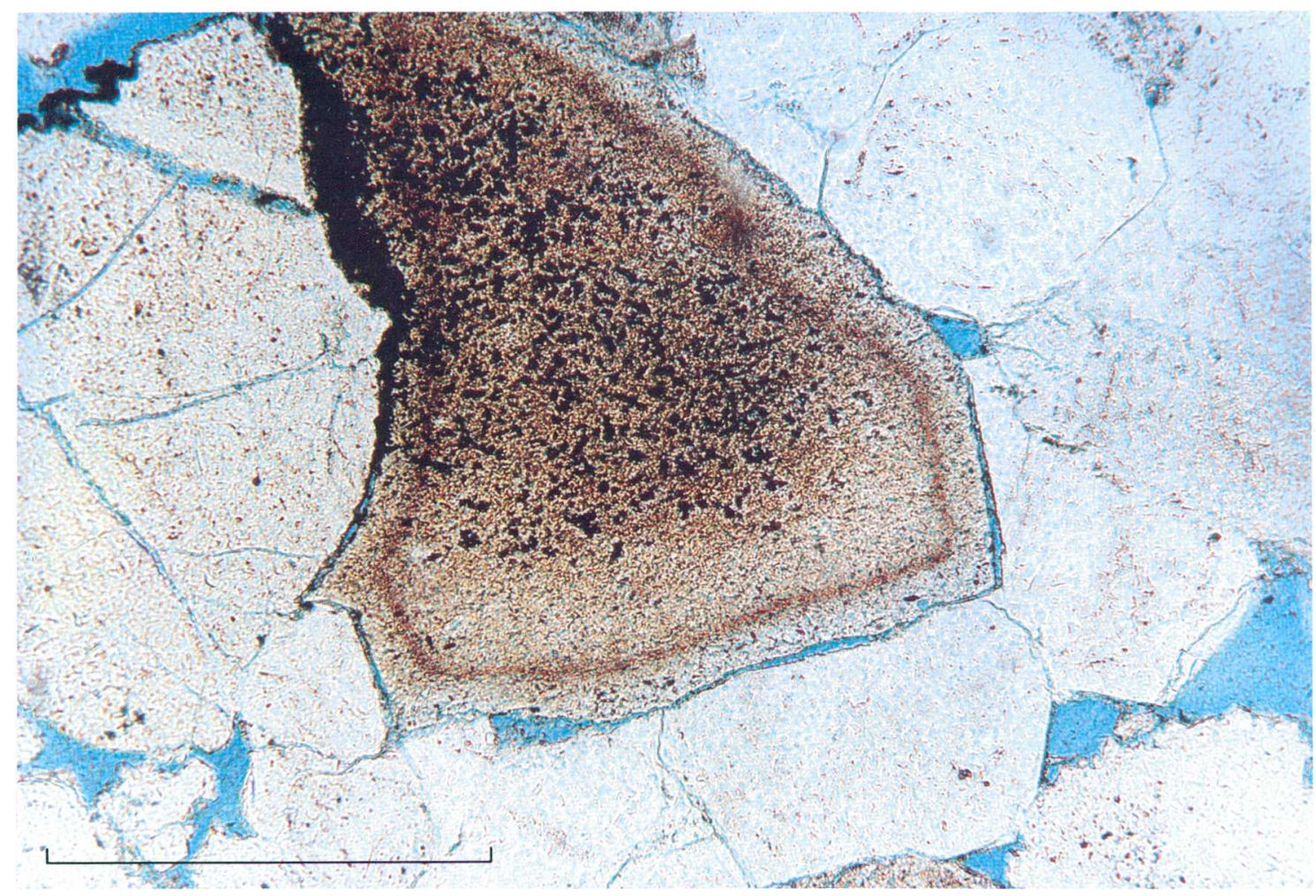

Figure 6. Diamond Peak Formation, south end of Buck Mountain; sample 791-15-2B (loc. 6, fig. 1); 9 percent visual porosity, 11.6 percent total porosity, and $13 \mathrm{mD}$ air permeability. Secondary porosity resulted from shrinkage of pelitic rock fragment. Euhedral quartz overgrowths fill primary pore space. Blue is visible porosity. Bar scale is $0.5 \mathrm{~mm}$. 


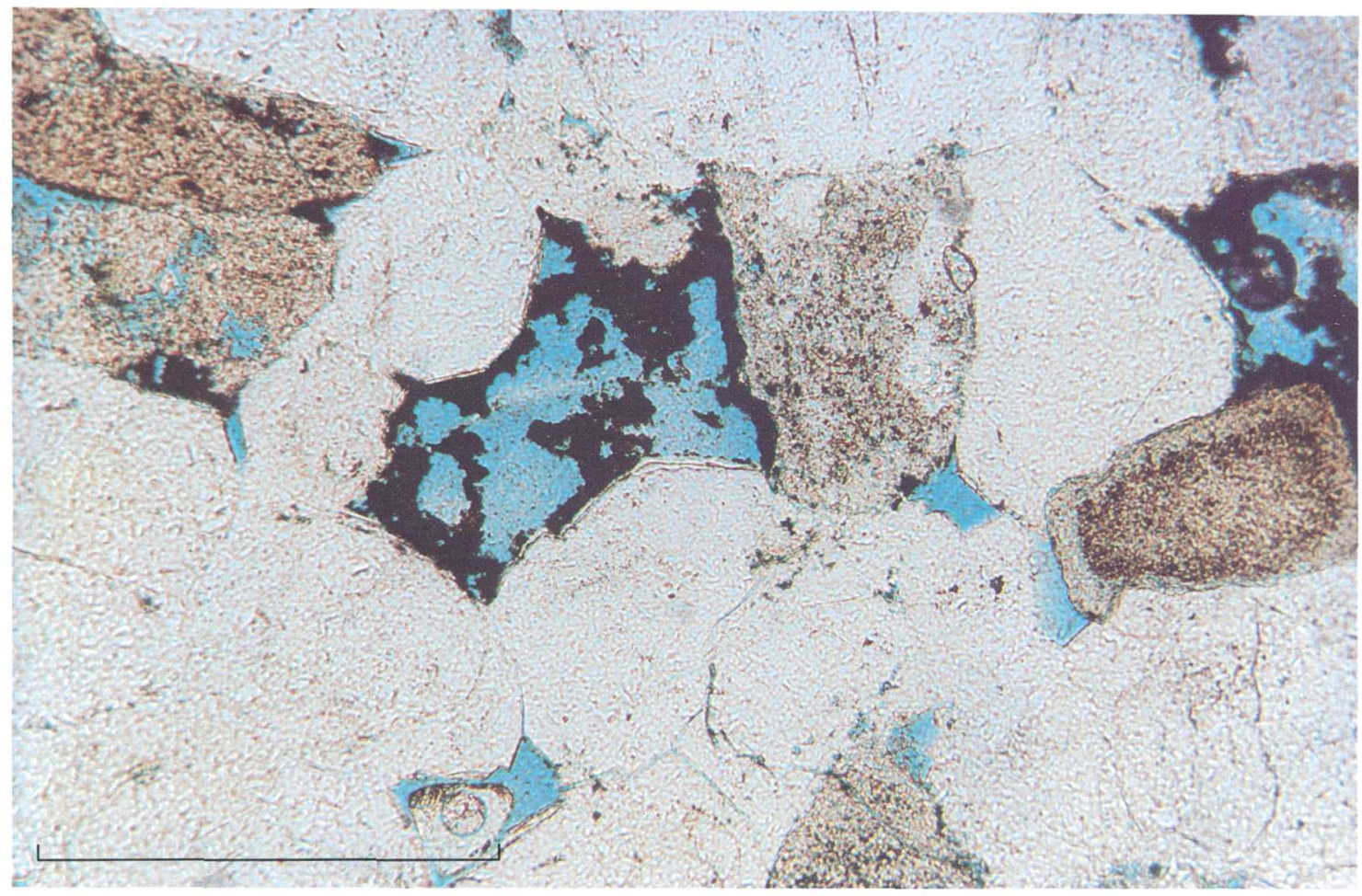

Figure 7. Diamond Peak Formation, south end of Buck Mountain; sample 791-15-2B (loc. 6, fig. 1); 9 percent visual porosity. Secondary porosity formed by dissolution of opaque rock fragment. Note euhedral quartz overgrowths and possible remnant primary pore in lower left of photograph. Blue is visible porosity. Bar scale is $0.5 \mathrm{~mm}$.

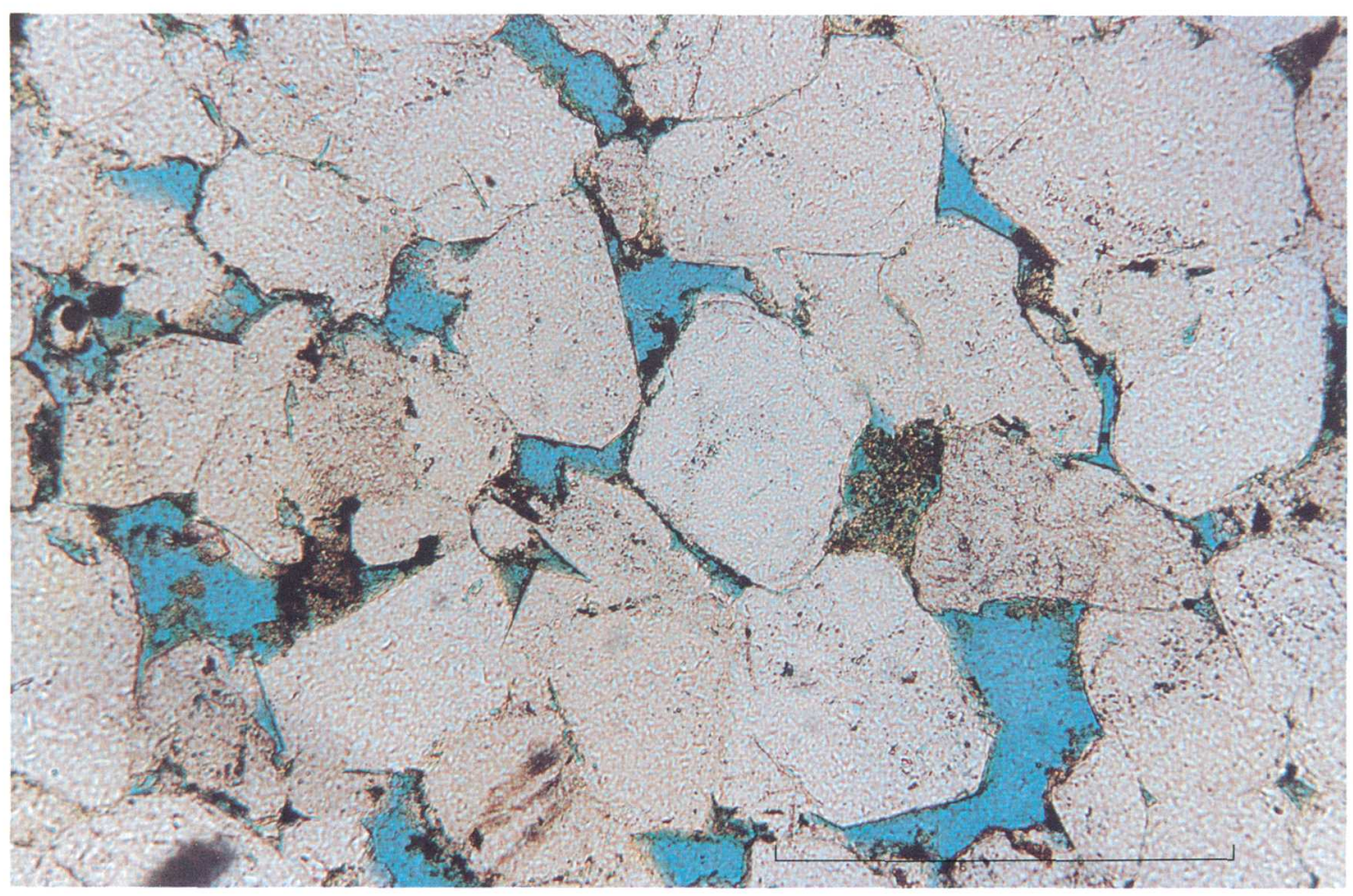

Figure 8. Quartzose sandstone of the Scotty Wash Quartzite, Trough Spring Canyon, southern Egan Range; sample 791-18-2A (loc. 15, fig. 1); 9 percent visible porosity, 11.6 percent total porosity, and $43 \mathrm{mD}$ air permeability. Note euhedral quartz overgrowths and secondary porosity formed by dissolution of calcareous intergranular cement (remnants line the pores). Blue is visible porosity. Bar scale is $0.5 \mathrm{~mm}$. 


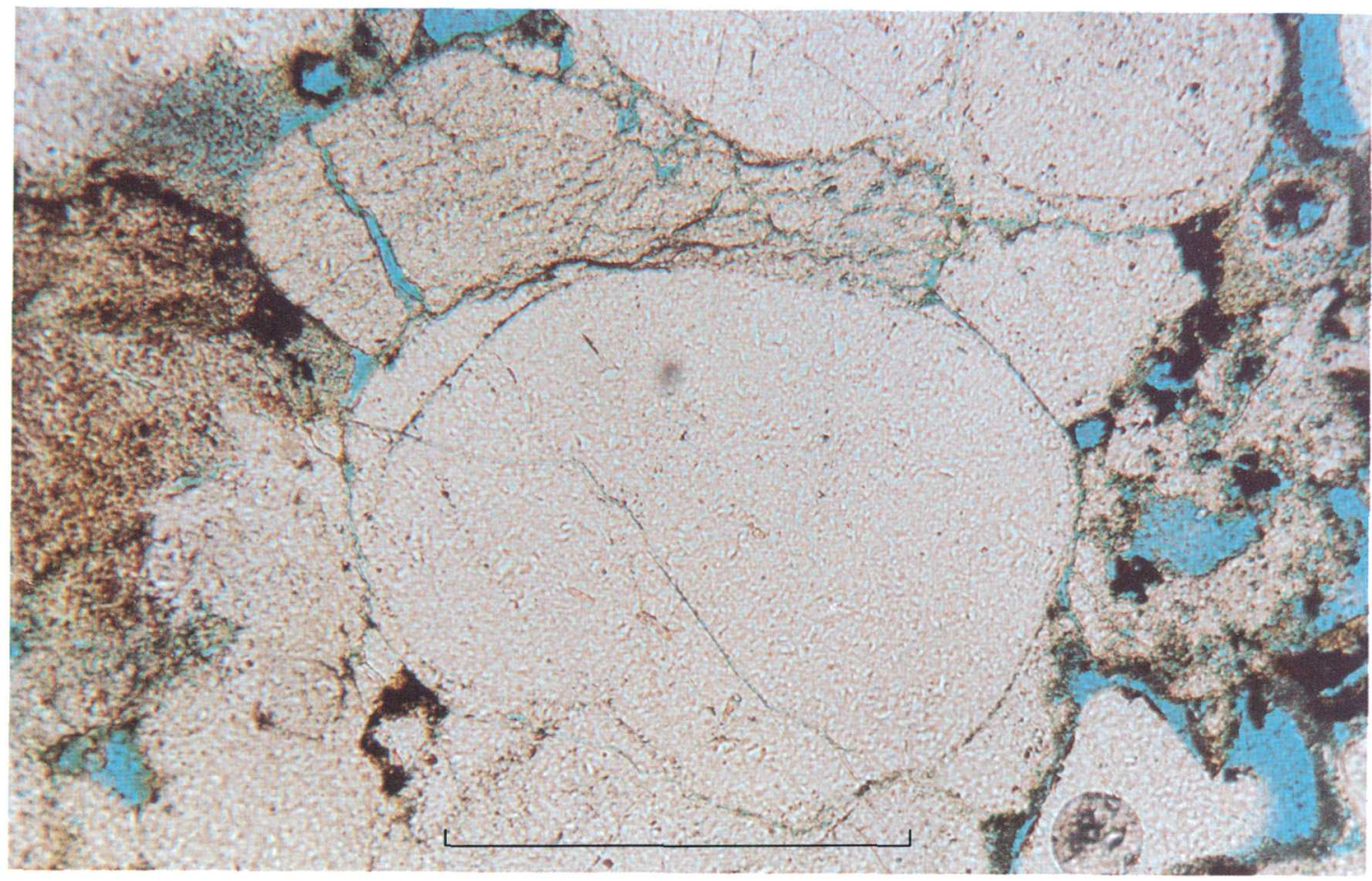

Figure 9. Secondary porosity in Diamond Peak Formation outcrop, south end of Buck Mountain; sample 791-15-4B (loc. 7, fig. 1); 10 percent visible porosity, 14.4 percent total porosity, and $38 \mathrm{mD}$ air permeability. Rock is cemented by compaction and precipitation of quartz overgrowths; secondary porosity is due to dissolution of rock fragments and to grain fracture. Blue is visible porosity. Bar scale is $0.5 \mathrm{~mm}$.

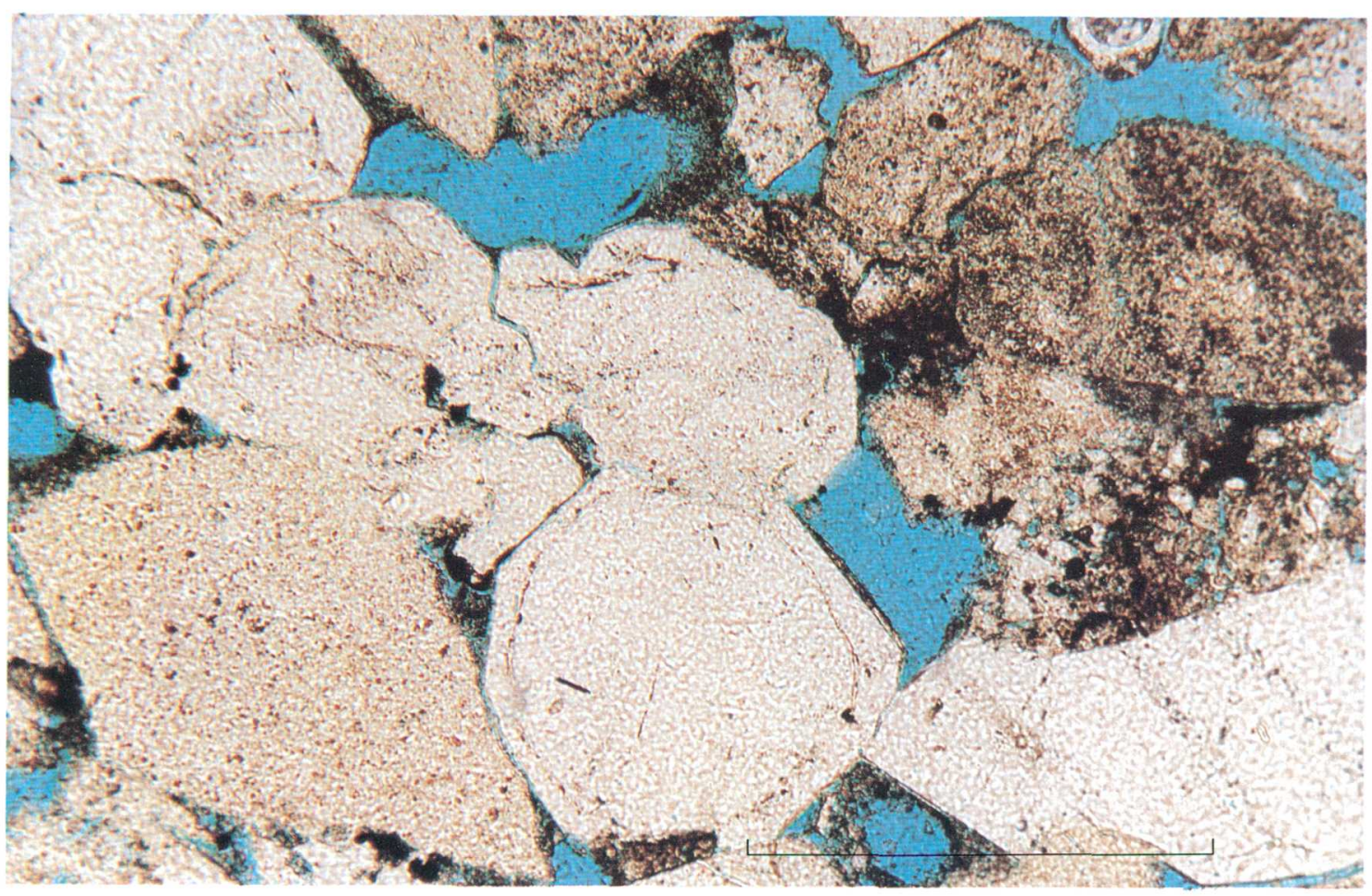

Figure 10. Diamond Peak Formation, Nevada Governors Spring, northern Pancake Range; sample 791-19-3 (loc. 17, fig. 1); 8 percent visible porosity, 8.4 percent total porosity, and $18 \mathrm{mD}$ air permeability. Primary porosity was reduced by compaction and precipitation of quartz overgrowths and then by precipitation of calcareous cement, which has been subsequently removed to form secondary pore space. Blue is visible porosity. Bar scale is $0.5 \mathrm{~mm}$. 


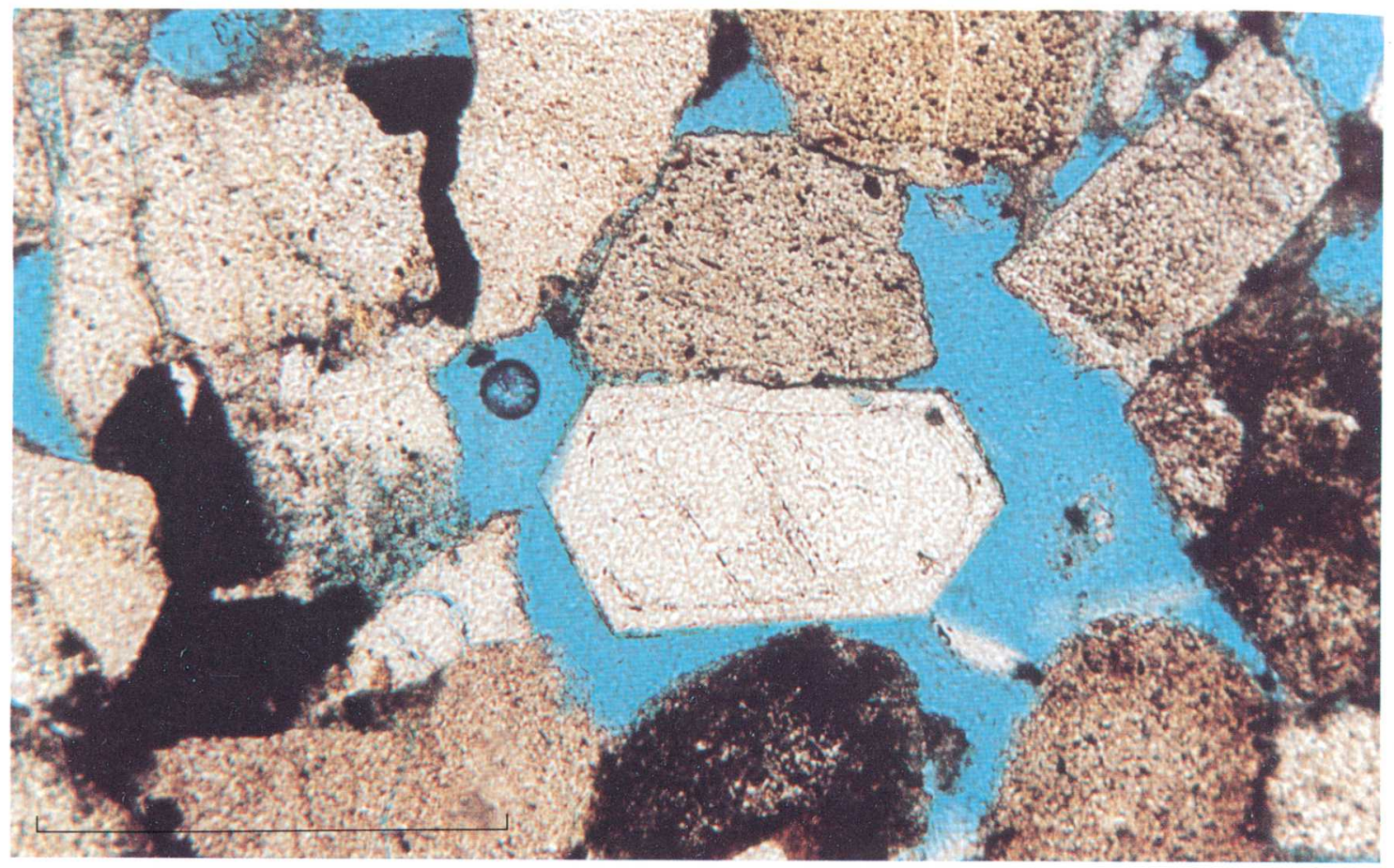

Figure 11. Diamond Peak Formation, Nevada Governors Spring, northern Pancake Range; sample 791-19-3 (loc. 17, fig. 1); 8 percent visible porosity, 8.4 percent total porosity, and $18 \mathrm{mD}$ air permeability. Quartz grain with doubly terminated overgrowth is surrounded on two sides by outsized secondary pore formed by dissolution of calcareous cement. Blue is visible porosity. Bar scale is $0.5 \mathrm{~mm}$.

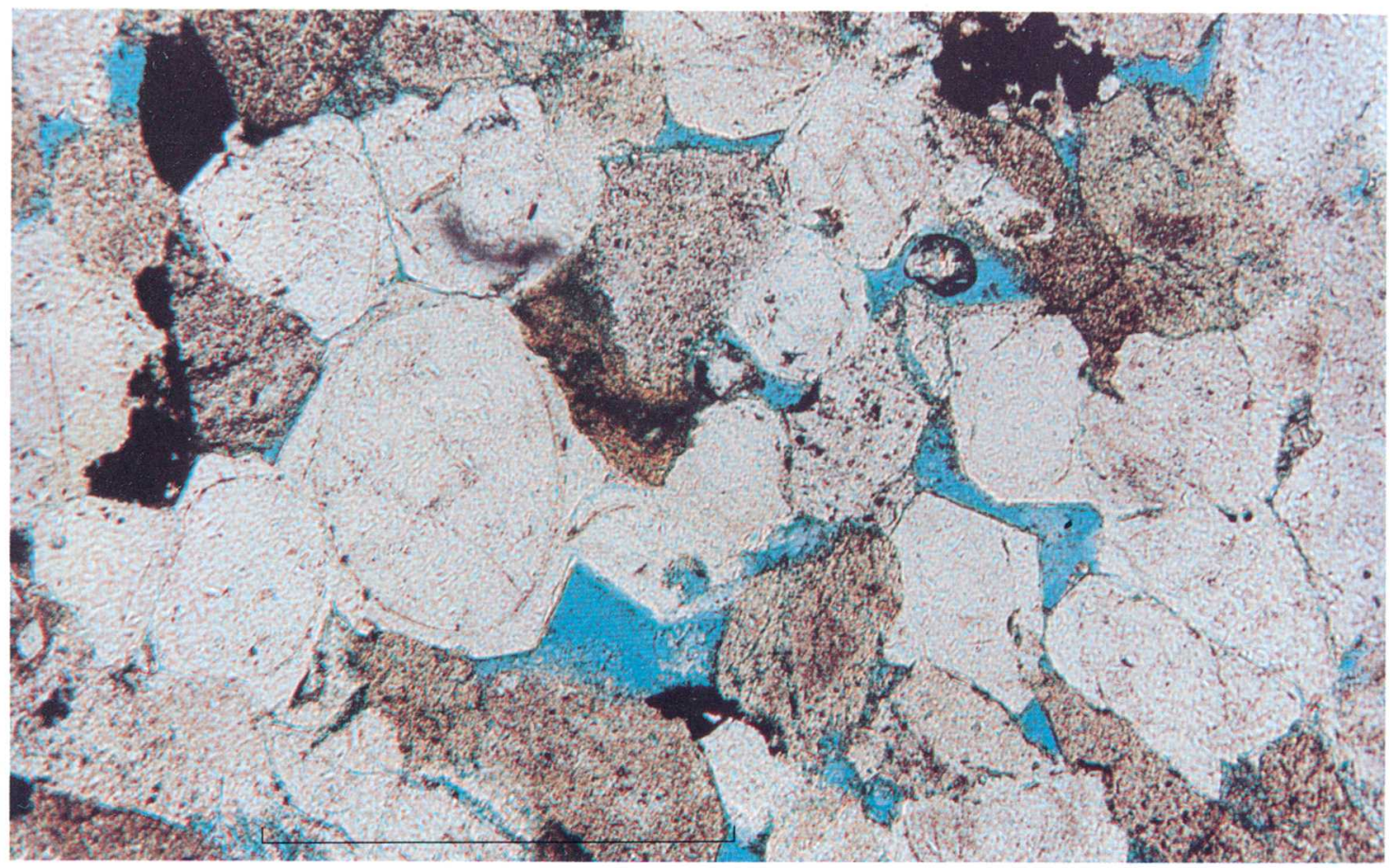

Figure 12. Diamond Peak Formation, Nevada Governors Spring, northern Pancake Range; sample 791-19-2A (loc. 17, fig. 1); 8 percent visible porosity, 13.1 percent total porosity; and $2.4 \mathrm{mD}$ air permeability. Textures suggest that primary porosity was eliminated by compaction and by precipitation of calcareous cement and that secondary porosity resulted from dissolution of the calcareous cement and rock fragments. The final event was precipitation of quartz (note overgrowths). Blue is visible porosity; arrow indicates location of pore shown in figure 13 . Bar scale is $0.5 \mathrm{~mm}$. 


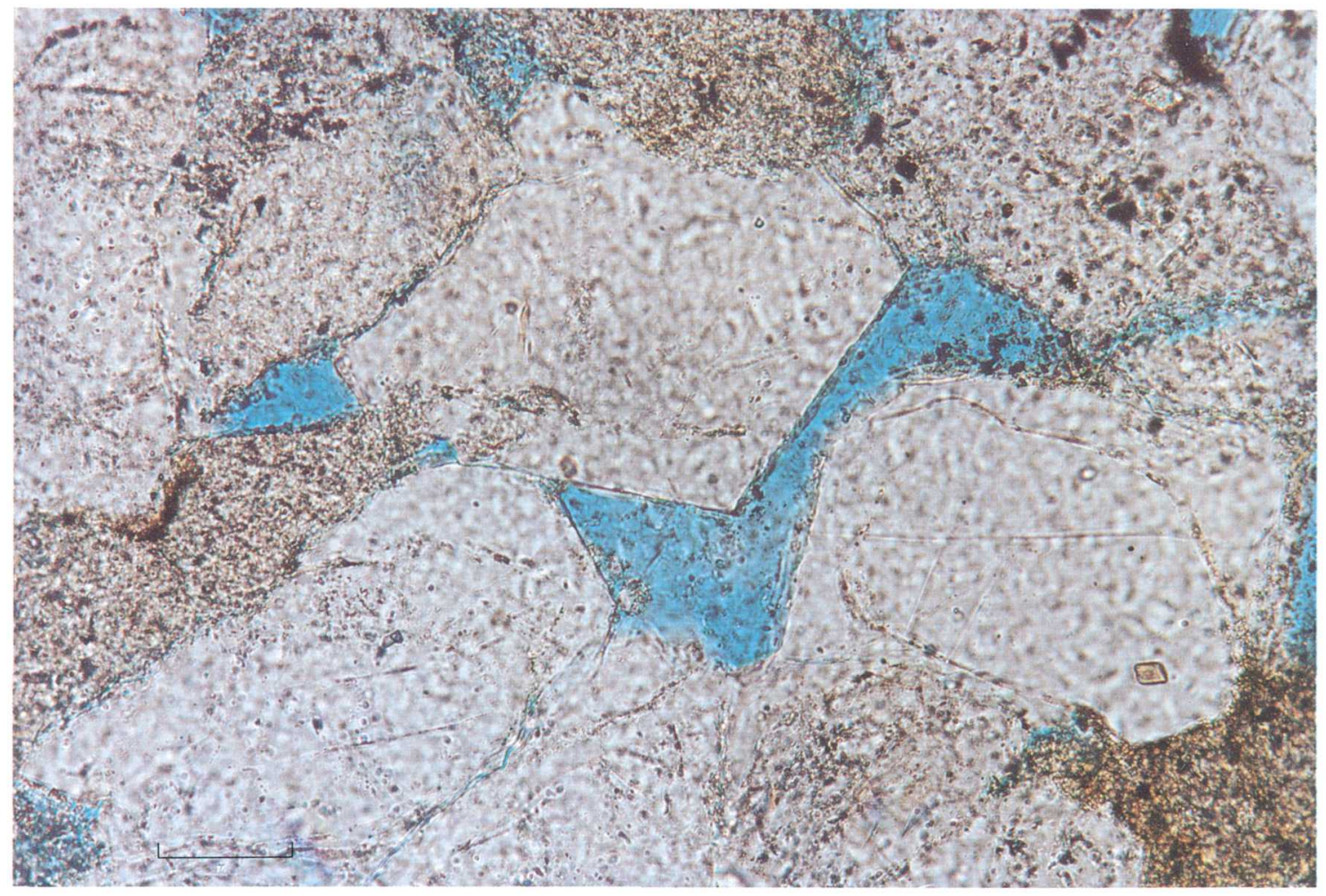

Figure 13. Closeup view of sample 791-19-2A showing euhedral quartz overgrowth and secondary pore space. Location of pore is shown by arrow in figure 12. Blue is visible porosity. Bar scale is $0.05 \mathrm{~mm}$.

pores are readily visible (figs. $14 A, B$ ). In some cases, quartz facets line the walls of pores (fig. 14A).

\section{PARAGENESIS OF CEMENTS}

In sandstones that contain both faceted quartz overgrowths and intergranular calcareous cement, corrosion of facets by adjacent calcite and (or) dolomite cement suggests that quartz precipitation preceded calcareous cementation. Textures illustrated in figures 10 and 11 indicate the complexities of cementation. Both figures show interpenetration of grain contacts that resulted from mechanical compaction. The two figures also show euhedral quartz overgrowths that project into visible pore space (blue areas), a texture that probably developed after dissolution of calcareous cement. Most of the blue areas in figures 10 and 11 were probably occupied by calcareous cement that corroded the margins of adjacent grains (note the ragged edges that project into the pore space). A lack of faceted quartz overgrowths in sandstones that have poikilotopic calcareous cement indicates that quartz precipitation was probably inhibited by early formed calcareous cement.

Petrographic textures illustrated in figures 12 and 13 suggest the following sequence of cementation. (1) Grains were pressed together by mechanical compaction. (Note the interpenetrating grains.) (2) Calcareous grains and (or) patchy calcareous intergranular cement precipitated, and adjacent quartz was corroded. (3) Secondary pores were created by dissolution of labile rock fragments and (or) calcareous cement. (4) Quartz overgrowths precipitated. (Note the delicate euhedral quartz facets that project into the pore (blue area) of figure 13.)

Preservation of matrix-supported grains that have smooth, well-rounded margins (grains that appear to float in calcareous cement) suggests that the calcareous cement precipitated prior to mechanical compaction. Such calcareous-cemented rocks tend to have little or no visible porosity and few or no quartz overgrowths.

\section{SUMMARY}

Mississippian siliciclastic sandstones of eastern Nevada range in composition from litharenite to quartzarenite. Their rock fragment content tends to decrease with distance from the principal sediment sources in the Roberts Mountains allochthon. Total porosity and permeability of calcareous cement-free sandstone are uniformly low in areas that have high paleotemperatures $\left(>300^{\circ} \mathrm{C}\right.$ ). Locally high paleotemperatures (Poole and others, 1983) in Paleozoic strata in eastern Nevada probably 

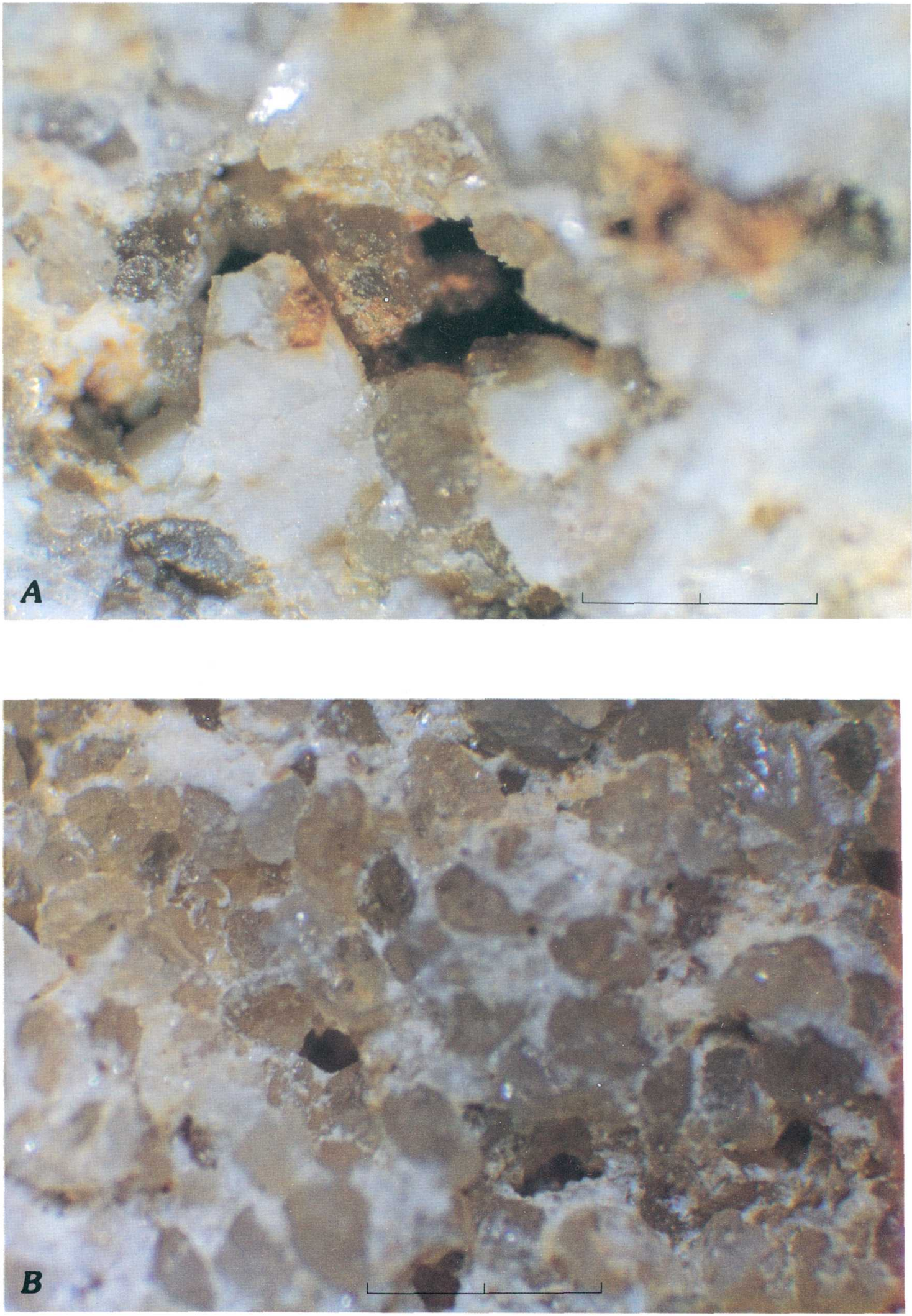

Figure 14. Dissolution pores (dark areas) and euhedral surfaces of quartz overgrowths (lightest areas) on surfaces cut with diamond saw and photographed using low-power $(\times 24)$ binocular microscope. Bar scales are $2.0 \mathrm{~mm}$. A, Diamond Peak Formation, south end of Buck Mountain, sample 791-15-4B (loc. 7, fig. 1). B, Scotty Wash Quartzite, Trough Spring Canyon, sample 791-18-3A (loc. 15, fig. 1). 
are due to thermal episodes associated with Mesozoic plutonism and Cenozoic volcanism. Indeed, still active hydrothermal heating is postulated for generating petroleum in Paleozoic source rocks in the most productive fields of eastern Nevada, the Grant Canyon and Bacon Flat oil fields in Railroad Valley (Hulen and others, 1994). Preservation of hydrocarbon-productive porosity and permeability in Mississippian sandstones in eastern Nevada probably depends on the delicate balance between a thermal regime that generates and facilitates migration of liquid hydrocarbons and excessive heat and adverse fluid dynamics that destroy source rocks and render potential reservoir rocks hard and tight.

\section{REFERENCES CITED}

Brew, D.A., 1963, Synorogenic sedimentation of Mississippian age, Eureka quadrangle, Nevada: Stanford, California, Stanford University, Ph.D. thesis, 260 p.

1971, Mississippian stratigraphy of the Diamond Peak area, Eureka County, Nevada, with a section on the Biostratigraphy and age of the Carboniferous formations by M. Gordon, Jr.: U.S. Geological Survey Professional Paper 661, 84 p.

Dickinson, W.R., 1970, Interpreting detrital modes of graywacke and arkose: Journal of Sedimentary Petrology, v. 40, p. 695-707.

Dickinson, W.R., Harbaugh, D.W., Saller, A.H., Heller, P.L., and Snyder, W.S., 1983, Detrital modes of upper Paleozoic sandstones from Antler orogen in Nevada-Implications for nature of Antler orogeny: American Journal of Science, v. 283, p. 481-509.

Dott, R.H., Jr., 1955, Pennsylvanian stratigraphy of Elko and northern Diamond Ranges, northeastern Nevada: American Association of Petroleum Geologists Bulletin, v. 39, no. 11, p. 2211-2305.

Goebel, K.A., 1991, Paleogeographic setting of Late Devonian to Early Mississippian transition from passive to collisional margin, Antler foreland, eastern Nevada and western Utah, in Cooper, J.D., and Stevens, C.H., eds., Paleozoic paleogeography of the Western United States-II: Pacific Section, Society of Economic Paleontologists and Mineralogists, v. 67, p. 401-418.

Harbaugh, D.W., 1980, Depositional facies and provenance of the Mississippian Chainman shale and Diamond Peak Formation, central Diamond Mountains, Nevada: Stanford, California, Stanford University, M.S. thesis, 81 p.

Harbaugh, D.W., and Dickinson, W.R., 1981, Depositional facies of Mississippian clastics, Antler foreland basin, central Diamond Mountains, Nevada: Journal of Sedimentary Petrology, v. 51, p. 1223-1234.

Hulen, J.B., Goff, Fraser, Ross, J.R., Bortz, L.C., and Bereskin, S.R., 1994, Geology and geothermal origin of Grant Canyon and Bacon Flat oil fields, Railroad Valley, Nevada: American Association of Petroleum Geologists Bulletin, v. 78, p. 596-623.

Ingersoll, R.V., Bullard, T.F., Ford, R.L., Pickle, J.D., and Sares, S.W., 1984, The effect of grain size on detrital modes-A test of the Gazzi-Dickinson point-counting method: Journal of Sedimentary Petrology, v. 54, p. 103-116.
Melvin, John, and Knight, A.S., 1984, Lithofacies, diagenesis and porosity of the Ivishak Formation, Prudhoe Bay area, Alaska, in McDonald, D.A., and Surdam, R.C., eds., Clastic diagenesis: American Association of Petroleum Geologists Memoir 37, p. 347-365.

Nolan, T.B., 1928, A Late Paleozoic positive area in Nevada: American Journal of Science, ser. 5, v. 16, no. 92, p. 153-161.

Nolan, T.B., Merriam, C.W., and Williams, J.S., 1956, The stratigraphic section in the vicinity of Eureka, Nevada: U.S. Geological Survey Professional Paper 276, 77 p.

Perry, A.J., and Trexler, J.H., Jr., 1993, Tectonic implications of sedimentation within the (Upper Mississippian) lower Newark Valley sequence, Diamond Mountains, Nevada: Cordilleran and Rocky Mountain Sections, Geological Society of America, Abstracts with Programs, v. 25, no. 5, p. 133.

Poole, F.G., 1974, Flysch deposits of the Antler Foreland basin, western United States, in Dickinson, W.R., ed., Tectonics and sedimentation: Society of Economic Paleontologists and Mineralogists Special Publication 22, p. 58-82.

Poole, F.G., and Claypool, G.E., 1984, Petroleum source-rock potential and crude-oil correlation in the Great Basin, in Woodward, Jane, Meissner, F.F., and Clayton, J.L., eds., Hydrocarbon source rocks of the Greater Rocky Mountain region: Denver, Rocky Mountain Association of Geologists, p. 179-229.

Poole, F.G., Claypool, G.E., and Fouch, T.D., 1983, Major episodes of petroleum generation in part of the northern Great Basin: Geothermal Resources Council Special Report 13, p. 207-213.

Poole, F.G., and Sandberg, C.A., 1991, Mississippian paleogeography and conodont biostratigraphy of the western United States, in Cooper, J.D., and Stevens, C.H., eds., Paleozoic paleogeography of the Western United States-II: Pacific Section, Society of Economic Paleontologists and Mineralogists, v. 67, p.107-136.

Roberts, R.J., Montgomery, K.M., and Lehner, R.E., 1967, Geology and mineral resources of Eureka County, Nevada: Nevada Bureau of Mines and Geology Bulletin 64, $152 \mathrm{p}$.

Schmidt, Volkmar, and McDonald, D.A., 1979, Texture and recognition of secondary porosity in sandstones, in Scholle, P.A., and Schluger, P.R., eds., Aspects of diagenesis: Society of Economic Paleontologists and Mineralogists Special Publication 26, p. 209-225.

Speed, R.C., and Sleep, N.H., 1982, Antler orogeny and foreland basin-A model: Geological Society of America Bulletin, v. 93, p. 815-828.

Trexler, J.H., Jr., and Cashman, P.H., 1990, The Diamond Mountain phase of the Antler orogeny-Late Mississippian compressional deformation in east-central Nevada: Geological Society of America Abstracts with Programs, v. 22, p. 274.

1991, Mississippian stratigraphy and tectonics of east-central Nevada-Post-Antler orogenesis, in Cooper, J.D., and Stevens, C.H., eds., Paleozoic paleogeography of the Western United States-II: Pacific Section, Society of Economic Paleontologists and Mineralogists, v. 67, p. 331-342.

Trexler, J.H., Jr., and Nitchman, S.P., 1990, Sequence stratigraphy of the Antler foreland basin, east-central Nevada: Geology, v. 18 , p. 422-425. 
Trexler, J.H., Jr., Snyder, W.S., Cashman, P.H., Gallegos, D.M., and Spinosa, Claude, 1991, Mississippian through Permian orogenesis in eastern Nevada-Post-Antler, pre-Sonoma tectonics of the western Cordillera, in Cooper, J.D., and Stevens, C.H., eds., Paleozoic paleogeography of the Western United
States-II: Pacific Section, Society of Economic Paleontologists and Mineralogists, v. 67, p. 317-329.

Westgate, L.G., and Knopf, Adolph, 1932, Geology and ore deposits of the Pioche district, Nevada: U.S. Geological Survey Professional Paper 171, 79 p.

Published in the Central Region, Denver, Colorado

Manuscript approved for publication December 1, 1994

Edited by Judith Stoeser

Graphics design by Denny Welp

Cartography by Springfield \& Springfield

Photocomposition by Denny Welp

Cover art by Art Isom 


\section{Periodicals}

Earthquakes \& Volcanoes (issued bimonthly).

Preliminary Determination of Epicenters (issued monthly).

\section{Technical Books and Reports}

Professional Papers are mainly comprehensive scientific reports of wide and lasting interest and importance to professional scientists and engineers. Included are reports on the results of resource studies and of topographic, hydrologic, and geologic investigations. They also include collections of related papers addressing different aspects of a single scientific topic.

Bulletins contain significant data and interpretations that are of lasting scientific interest but are generally more limited in scope or geographic coverage than Professional Papers. They include the results of resource studies and of geologic and topographic investigations; as well as collections of short papers related to a specific topic.

Water-Supply Papers are comprehensive reports that present significant interpretive results of hydrologic investigations of wide interest to professional geologists, hydrologists, and engineers. The series covers investigations in all phases of hydrology, including hydrology, availability of water, quality of water, and use of water.

Circulars present administrative information or important scientific information of wide popular interest in a format designed for distribution at no cost to the public. Information is usually of short-term interest.

Water-Resources Investigations Reports are papers of an interpretive nature made available to the public outside the formal USGS publications series. Copies are reproduced on request unlike formal USGS publications, and they are also available for public inspection at depositories indicated in USGS catalogs.

Open-File Reports include unpublished manuscript reports, maps, and other material that are made available for public consultation at depositories. They are a nonpermanent form of publication that may be cited in other publications as sources of information.

\section{Maps}

Gcologic Quadrangle Maps are multicolor geologic maps on topographic bases in $71 / 2$ - or 15-minute quadrangle formats (scales mainly $1: 24,000$ or $1: 62,500$ ) showing bedrock, surficial, or engineering geology. Maps generally include brief texts; some maps include structure and columnar sections only.

Geophysical Investigations Maps are on topographic or planimetric bases at various scales, they show results of surveys using geophysical techniques, such as gravity, magnetic, seismic, or radioactivity, which reflect subsurface structures that are of economic or geologic significance. Many maps include correlations with the geology.

Miscellaneous Investigations Series Maps are on planimetric or topographic bases of regular and irregular areas at various scales; they present a wide variety of format and subject matter. The series also includes 7 1/2-minute quadrangle photogeologic maps on planimetric bases which show geology as interpreted from aerial photographs. The series also includes maps of Mars and the Moon.
Coal Investigations Maps are geologic maps on topographic or planimetric bases at various scales showing bedrock or surficial geology, stratigraphy, and structural relations in certain coal-resource areas.

Oil and Gas Investigations Charts show stratigraphic information for certain oil and gas fields and other areas having petroleum potential.

Miscellaneous Field Studies Maps are multicolor or black-andwhite maps on topographic or planimetric bases on quadrangle or irregular areas at various scales. Pre-1971 maps show bedrock geology in relation to specific mining or mineral-deposit problems; post-1971 maps are primarily black-and-white maps on various subjects such as environmental studies or wilderness mineral investigations.

Hydrologic Investigations Atlases are multicolored or black-andwhite maps on topographic or planimetric bases presenting a wide range of geohydrologic data of both regular and irregular areas; the principal scale is $1: 24,000$, and regional studies are at $1: 250,000$ scale or smaller.

\section{Catalogs}

Permanent catalogs, as well as some others, giving comprehensive listings of U.S. Geological Survey publications are available under the conditions indicated below from USGS Map Distribution, Box 25286 , Building 810, Denver Federal Center, Denver, CO 80225. (See latest Price and Availability List.)

"Publications of the Geological Survey, 1879-1961" may be purchased by mail and over the counter in paperback book form and as a set microfiche.

"Publications of the Geological Survey, 1962-1970"may be purchased by mail and over the counter in paperback book form and as a set of microfiche.

"Publications of the U.S. Geological Survey, 1971-1981" may be purchased by mail and over the counter in paperback book form (two volumes, publications listing and index) and as a set of microfiche.

Supplements for 1982, 1983, 1984, 1985, 1986, and for subsequent years since the last permanent catalog may be purchased by mail and over the counter in paperback book form.

State catalogs, "List of U.S. Geological Survey Geologic and Water-Supply Reports and Maps For (State)," may be purchased by mail and over the counter in paperback booklet form only.

"Price and Availability List of U.S. Geological Survey Publications," issued annually, is available free of charge in paperback booklet form only.

Selected copies of a monthly catalog "New Publications of the U.S. Geological Survey" is available free of charge by mail or may be obtained over the counter in paperback booklet form only. Those wishing a free subscription to the monthly catalog "New Publications of the U.S. Geological Survey" should write to the U.S. Geological Survey, $582 \mathrm{Na}$ tional Center, Reston, VA 22092.

Note.-Prices of Government publications listed in older catalogs, announcements, and publications may be incorrect. Therefore, the prices charged may differ from the prices in catalogs, announcements, and publications. 


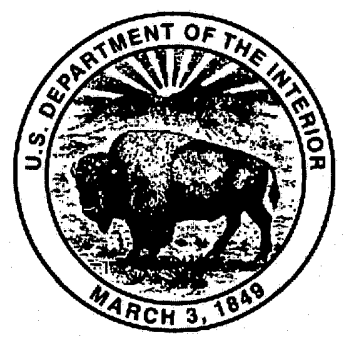

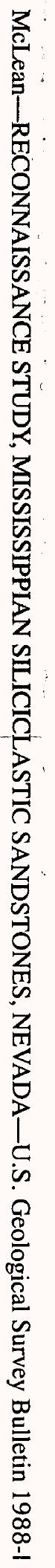

